\title{
Updated distribution and biogeography of amphibians and reptiles of Europe
}

\author{
Neftali Sillero ${ }^{1, *}$, João Campos ${ }^{1}$, Anna Bonardi ${ }^{2}$, Claudia Corti ${ }^{3}$, Raymond Creemers ${ }^{4}$, \\ Pierre-Andre Crochet ${ }^{5}$, Jelka Crnobrnja Isailović6,7, Mathieu Denoël ${ }^{8}$, Gentile Francesco Ficetola ${ }^{2}$, \\ João Gonçalves ${ }^{9}$, Sergei Kuzmin ${ }^{10}$, Petros Lymberakis ${ }^{11}$, Philip de Pous ${ }^{12,13}$, Ariel Rodríguez ${ }^{14}$, \\ Roberto Sindaco $^{15}$, Jeroen Speybroeck ${ }^{16}$, Bert Toxopeus ${ }^{17}$, David R. Vieites ${ }^{18,19}$, Miguel Vences ${ }^{14}$
}

\begin{abstract}
A precise knowledge of the spatial distribution of taxa is essential for decision-making processes in land management and biodiversity conservation, both for present and under future global change scenarios. This is a key base for several scientific disciplines (e.g. macro-ecology, biogeography, evolutionary biology, spatial planning, or environmental impact assessment) that rely on species distribution maps. An atlas summarizing the distribution of European amphibians and reptiles with $50 \times 50 \mathrm{~km}$ resolution maps based on ca. 85000 grid records was published by the Societas Europaea Herpetologica (SEH) in 1997. Since then, more detailed species distribution maps covering large parts of Europe became available, while taxonomic progress has led to a plethora of taxonomic changes including new species descriptions. To account for these progresses, we compiled information from different data sources: published in books and websites, ongoing national atlases, personal data kindly provided to the SEH, the 1997 European Atlas, and the Global Biodiversity Information Facility (GBIF). Databases were homogenised, deleting all information except species names and coordinates, projected to the same coordinate system (WGS84) and transformed into a $50 \times 50 \mathrm{~km}$ grid. The newly compiled database comprises more than 384000 grid and locality records distributed across 40 countries. We calculated species richness maps as well as maps of Corrected Weighted Endemism and defined species distribution types (i.e. groups of species with similar distribution patterns) by hierarchical cluster analysis using Jaccard's index as association measure. Our analysis serves as a preliminary step towards an interactive, dynamic and online distributed database system (NA2RE system) of the current spatial distribution of European amphibians and reptiles. The NA2RE system will serve as well to monitor potential temporal changes in their distributions. Grid maps of all species are made available along with this paper as a tool for decision-making and conservation-related studies and actions. We also identify taxonomic and geographic gaps of knowledge that need to be filled, and we highlight the need to add temporal and altitudinal data for all records, to allow tracking potential species distribution changes as well as detailed modelling of the impacts of land use and climate change on European amphibians and reptiles.
\end{abstract}

Keywords: biogeography, conservation, distribution atlas, distribution types, endemism, European herpetofauna, IUCN red list, species richness.

1 - Centro de Investigação em Ciências Geo-Espaciais, Alameda do Monte da Virgem, 4430-146 Vila Nova de Gaia, Portugal

2 - Department of Earth and Environmental Sciences, Università di Milano-Bicocca, Piazza della Scienza 1, 20126 Milano, Italy

3 - Museo di Storia Naturale dell'Università di Firenze, Sezione di Zoologia "La Specola", Via Romana 17, 50125 Firenze, Italia

4 - RAVON, Postbus 1413, 6501 BK Nijmegen, The Netherlands

5 - CNRS-UMR5175 CEFE, Centre d'Ecologie Fonctionnelle et Evolutive, 1919, route de Mende, 34293 Montpellier, France

6 - Department of Biology and Ecology, Faculty of Sciences and Mathematics, University of Niš, Višegradska 33, 18000 Niš, Serbia
7 - Department of Evolutionary Biology, Institute for Biological Research "Siniša Stanković”, University of Belgrade, Despota Stefana 142, 11000 Beograd, Serbia

8 - F.R.S. - FNRS Research Associate, Behavioural Biology Unit, University of Liège, 22 Quai van Beneden, 4020 Liege, Belgium

9 - CIBIO, University of Porto, R. Campo Alegre 687, 4169-007 Porto, Portugal

10 - Institute of Ecology and Evolution, Russian Academy of Sciences, Moscow 117071, Russia

11 - Natural History Museum of Crete, University of Crete, Knossou Ave., P.O. Box 2208, 71409 Heraklion Crete, Greece

12 - Faculty of Life Sciences and Engineering, Universitat de Lleida, Av. Rovira Roura 191, 25198 Lleida, Spain

13 - Institut de Biologia Evolutiva (CSIC-Universitat Pompeu Fabra), Animal Phylogeny and Systematics, 


\section{Introduction}

A good knowledge on the geographical distribution of organisms is pivotal for macroecological and evolutionary studies, as well as to inform policy makers in decisions on land management, health, climate change and biodiversity conservation (Jetz, McPherson and Guralnick, 2011). The availability of reliable maps that depict the historical and current distribution of species therefore constitutes an important component in conservation-related research. Data on their extent of occurrence are crucial for assigning IUCN threat categories to species (IUCN, 2001). This has for instance been a strategy in the Global Amphibian Assessment (Stuart et al., 2004) which provided the first comprehensive estimate of threat categories and distribution ranges of amphibians worldwide, a taxon that constitutes an important model group in conservation biology (e.g. Hopkins, 2007). Furthermore, many amphibian species and at least some groups of reptiles are undergoing severe global declines (Wake and Vredenburgh, 2008; Sinervo et al., 2010; Böhm et al., 2013), making their conservation a prime challenge and gathering data on their current distribution a top research priority.

Passeig Marítim de la Barceloneta 37-49, 08003 Barcelona, Spain

14 - Technische Universität Braunschweig, Division of Evolutionary Biology, Zoological Institute, Mendelssohnstr. 4, 38108 Braunschweig, Germany

15 - c/o Museo Civico di Storia Naturale, via San Francesco di Sales 88, 10022 Carmagnola (TO), Italia

16 - Research Institute for Nature and Forest, Kliniekstraat 25, 1070 Brussels, Belgium

17 - University of Twente, Faculty of Geo-Information Science and Earth Observation (ITC), P.O. Box 217, 7500 AA Enschede, The Netherlands

18 - Museo Nacional de Ciencias Naturales and Consejo Superior de Investigaciones Científicas, c/José Gutierrez Abascal 2, 28006 Madrid, Spain

19 - REFER Biodiversity Chair, University of Porto, CIBIO, Campus Agrário de Vairão, R. Padre Armando Quintas, 4485-661 Vairão, Portugal

*Corresponding author; e-mail: neftali.sillero@gmail.com
In European herpetology, shortly after the Societas Europaea Herpetologica (SEH) was established in 1979, it became evident that a comprehensive assessment of the distribution of all European amphibians and reptiles should receive priority, as basic maps where lacking. A mapping committee of the SEH was established in 1983, coordinated by a team based at the Muséum National d'Histoire Naturelle in Paris. From the work of regional and national coordinators, more than 85000 grid records were collected and shown in maps of $50 \times 50 \mathrm{~km}$ resolution produced by the Service du Patrimoine Naturel (Paris, France). This resulted in a distribution atlas published in 1997 (Gasc et al., 1997). This work, which in the following will for brevity be referred to as 'the 1997 European Atlas', has subsequently provided the basis for numerous studies, such as several conservation-oriented modelling approaches (e.g. Araújo and Pearson, 2005; Araújo et al., 2005; Araújo, Thuiller and Pearson, 2006; Araújo et al., 2008).

After the publication of the 1997 European Atlas, there has been a high intensity of mapping efforts and related research in $\mathrm{Eu}-$ rope. Numerous regional and national societies have since then produced detailed amphibian and reptile distributional information covering large parts of Europe, more detailed and reliable than the 1997 European Atlas. Many of these were published in the form of regional or national atlases (e.g. Bitz et al., 1996; Günther, 1996; Pleguezuelos, 1997; Cabela, Grillitsch and Tiedemann, 2001; Hofer, Monney and Dušej, 2001; Pleguezuelos, Lizana and Márquez, 2002; Głowaciński and Rafiński, 2003; Puky, Schad and Szövenyi, 2006; Sindaco et al., 2006; Jacob et al., 2007; Lanza et al., 2007; Laufer, Klemens and Sowig, 2007; Proess, 2007; Creemers and van Delft, 2009; Corti et al., 2010; Loureiro et al., 2010). Some of them (e.g. UK, Netherlands, Wallonia, Flanders, Switzerland) were published also through publicly available internet resources. Others, like the atlas of Sweden, were published exclu- 
sively on the internet. This wealth of novel data claims for an update of the herpetofaunal distribution data also at the European level, to quantify Europe-wide the improvement in knowledge since the previous Atlas, as well as a first step towards tracking potential changes in the distribution of the European herpetofauna in the context of global change.

Novel technologies for mapping species distributions currently available, such as newly developed Geographic Information Systems (Longley et al., 2010) and their extensions, offer the possibility of establishing extensive databases of distribution records, with associated metadata such as voucher specimen lists or photos. Citizen-science online tools allow contributors entering their observations, and directly link them to analysis tools such as spatial modelling or the production of customised maps. The current Mapping Committee of the SEH (established in 2006), together with the SEH Council and some associated fellows, has acknowledged that distribution atlases should be conceived as dynamic tools, implemented in a way that allows for continuous updates, extension changes, and customised data extraction while respecting the copyright that particular organisations or individuals might hold on parts of the underlying data. The goal is to establish a Spatial Data Infrastructure, a system of geographically distributed systems, where the original data remain on the servers controlled by national or regional herpetological societies, and through an online network it is possible to make data queries via the SEH portal (Sillero et al., 2014; see http:// na2re.ismai.pt). For countries that do not have national databases, the SEH works on establishing a connected database linked to an internet portal for data collection.

A dynamic online atlas of European amphibians and reptiles based on an underlying distributed database of distribution records represents a major logistic challenge and is timeconsuming. However, considering the current conservation crisis faced by many European amphibians and reptiles (Cox, Chanson and Stu- art, 2006), it is an urgent task to make updated distributional information on these organisms available. The species distribution maps of the 1997 European Atlas (Gasc et al., 1997) have never been made available in GIS format. However useful and original at the time, they are now outdated due to the considerable accumulation of new distribution data, and especially because of the taxonomic progress that resulted in multiple changes of genus-level classification, and a large number of new species descriptions (Speybroeck, Beukema and Crochet, 2010; Vences et al., 2013). This new taxonomy resulted in many species being split into multiple entities for which the exact distribution limits are poorly known.

The goal of the present study is to provoke and facilitate filling of these gaps by making updated distribution maps for the European herpetofauna available. For this purpose, we have compiled information from a large number of published and partly unpublished mapping efforts at a variety of spatial scales and transformed those data into a $50 \times 50 \mathrm{~km}$ UTM grid, similar to the one used for the $1997 \mathrm{Eu}-$ ropean Atlas. Based on this new compilation of maps, all of which are made available (see online Supplementary Atlas S1-S5 online), we here (1) identify the major spatial and taxonomic gaps in the currently available knowledge in order to identify future research priorities, and (2) analyse patterns of species richness, endemism and main distribution types (i.e. groups of species with similar distribution patterns) for European amphibians and reptiles.

\section{Materials and methods}

Study area

This compilation included almost the same area as the 1997 European Atlas (Gasc et al., 1997). We used the limits for Europe (see Supplementary fig. S1 online) provided by Geocommons (http://geocommons.com/overlays/76975). The geographical limits of the previous SEH 1997 European atlas were those defined by Mertens and Wermuth (1960), covering parts or the whole of 45 countries. Partial territories included were: north-western tip of Turkey (European Turkey), territories in the Russian Federation west of the 
Urals, north-eastern tip of Azerbaijan, north-western tip of Kazakhstan, Greece minus the Sporades Islands. However, the Geocommons limits do not include parts of Azerbaijan and Kazakhstan, while the Ural limits are defined more precisely. These limits for Europe are widely accepted by many geographical atlases (e.g. Cheers, 2005).

\section{Taxa}

For historical consistency and to facilitate reading, in this paper we use the traditional term 'reptiles' for the paraphyletic group including the vertebrate orders Squamata, Testudines, Crocodylia, and Rhynchocephalia, i.e. Sauropsida excluding birds (of which only Squamata and Testudines are represented in Europe's extant fauna). The species-level taxa considered in this compilation were determined by the SEH, using Speybroeck, Beukema and Crochet (2010) as starting point (see Supplementary Text S1 online). In numerous cases, although the species status of two or more related taxa is undisputed, we were unable to assign all available records to a species. This was either because the original databases had been compiled following an outdated taxonomy, or because many records could not be identified up to species level in the field (such as for instance, Triturus marmoratus and T. pygmaeus in the Iberian Peninsula). In these cases, we merged the respective species into a single entry in our database, which therefore in several cases represents a simplification of current taxonomy.

The sampling effort was obviously not homogeneous across the whole study area. Some countries have a very good knowledge on the ranges of their species while others have large gaps of chorological information. Although the present compilation is represented at a rather coarse scale $(50 \times 50 \mathrm{~km}$ grid $)$, gaps in the species distributions are still observable. Similarly, not all national and regional data sets are fully consistent in their treatment of marine and introduced species. Where available, our compilation includes terrestrial as well as marine taxa (i.e. marine turtles). Besides native species and populations, a number of national data sets also included introductions, i.e. introduced species from outside Europe as well as introduced populations of European species occurring outside their natural range. In this case our compilation is not fully consistent. For marine turtles, some countries included records on sightings (on coast and ocean) and reproduction places (i.e. Portugal and Spain), while other countries only included reproduction places (i.e. Italy and Balkan countries). In general, we did not include single records of escaped exotic species where there was no indication of naturalised populations. For non exotics, we considered as introduced those cases where the origin of the introduction is well known and can be traced back into recent history, such as the populations of Discoglossus pictus in southern France and in Spain (Catalonia), but not those cases where ancient introductions are suspected (e.g. various species on Mediterranean islands). In this sense, much of the actual herpetofaunal composition in the Mediterranean is probably related to or at least influenced by human activities (Corti et al., 1999).

\section{Database compilation}

Our goal in compiling updated distribution maps for the European fauna was to cover as many European countries as possible with national atlas data or new personal records. The species data included in these updated maps were obtained from different data sources, namely (1) published (in books or websites) or on-going national atlases, (2) personal data kindly provided to the SEH, (3) the 1997 European Atlas, and (4) the Global Information Facility (GBIF: www.gbif.org). Because the GBIF data originate from many different data sources and contain numerous errors and discrepancies, we tried to minimise their use as explained below. However, a few of the national atlas data were directly available only from GBIF (e.g. Denmark and Norway) and in these cases, the data were labelled as National Atlas Data rather than as GBIF data. Some countries provided databases used in already published atlases (whole database with temporal data series: e.g. Spain and Portugal; simplified database: e.g. The Netherlands) or before publishing as an atlas (e.g. Slovenia and France). For other countries, we digitised the data from published books (e.g. Hungary). We also included large unpublished databases for several countries compiled by some co-authors of this study (e.g. S.L. Kuzmin, P. de Pous). In the case of territories of former Yugoslavia, J. Crnobrnja Isailović and collaborators provided some of the original data used in the $1997 \mathrm{Eu}-$ ropean Atlas. National atlases and personal databases were subsequently merged in one database, which in the following will be referred to as COUNTRIES. A second database, hereafter named SEH/GBIF database, contained the data of the 1997 European Atlas and GBIF, but only for those countries for which no national atlas data were available. For the final compilation, the same exclusion strategy was also employed at the level of single UTM squares. Whenever a record from the COUNTRIES database was available for a UTM grid (only in personal databases: e.g. S.L. Kuzmin's personal database) we used that one rather than the duplicate record from the SEH/GBIF database. This process was performed using spatial queries in ArcGIS 9.3.

Many original databases contained erroneous records. The databases were therefore reviewed and validated by members of the SEH Council and its Mapping Committee in various rounds. Erroneous records were excluded from the two main databases (COUNTRIES and SEH/GBIF) and stored in a different file. During this revision of the point locality data in the COUNTRIES and SEH/GBIF database, we furthermore flagged introduced species and species locations, and these were transferred to a third database hereafter called INTRODUCED. As such, we never deleted a record: keeping all erroneous records rather than simply deleting them allowed tracking validation errors and makes our decisions verifiable. Introduction records were defined using our current knowledge, which is not homogeneous, thus bias may be present for some species and regions.

The three databases were composed by point records. The numerous data (table 1; 30 databases) have been received in multiple digital formats, with disparate information and in different spatial resolutions (ranging from point centroids of $50 \times 50 \mathrm{~km} \mathrm{UTM}$ grid cells to very precise 
Table 1. List of databases used in this atlas compilation. Resolution, records, and sources refer to data obtained and used for the compilation of the European atlas. References to published atlases are mentioned. Some of these databases included more than one country (e.g. S.L. Kuzmin). See table 2 for number of records per country.

\begin{tabular}{|c|c|c|c|c|}
\hline & Resolution & Records & Sources & Published atlases \\
\hline \multicolumn{5}{|l|}{ NATIONAL DATABASES } \\
\hline Austria & $5 \times 5 \mathrm{~km}$ & 14136 & digitised from Atlas & $\begin{array}{l}\text { Cabela, Grillitsch and } \\
\text { Tiedemann, } 2001\end{array}$ \\
\hline Bosnia and Herzegovina & $10 \times 10 \mathrm{~km}$ & 152 & $\begin{array}{l}\text { provided by D. Dobrnjić and } \\
\text { E. Tanović }\end{array}$ & \\
\hline Brussels & $10 \times 10 \mathrm{~km}$ & 59 & provided by Natagora & Weiserbs and Jacob, 2005 \\
\hline Bulgaria & $10 \times 10 \mathrm{~km}$ & 3170 & digitised from website & $\begin{array}{l}\text { http://www.oocities.org/ } \\
\text { herpetology_bg/ }\end{array}$ \\
\hline Estonia & $10 \times 10 \mathrm{~km}$ & 2872 & provided by Riinu Rannap & \\
\hline Flanders & $5 \times 5 \mathrm{~km}$ & 38945 & provided by Natuurpunt-Hyla & Bauwens and Claus, 1996 \\
\hline France & $50 \times 50 \mathrm{~km}$ & 11071 & $\begin{array}{l}\text { provided by Service du } \\
\text { Patrimoine Naturel (Muséum } \\
\text { National d'Histoire Naturelle) }\end{array}$ & $\begin{array}{l}\text { Lescure and De Massary, } \\
2012\end{array}$ \\
\hline Germany & $10 \times 10 \mathrm{~km}$ & 31065 & digitised from Atlas & Günther, 1996 \\
\hline Greece & exact coordinates & 9893 & provided by P. Lymberakis & Valakos et al., 2008 \\
\hline Hungary & $10 \times 10 \mathrm{~km}$ & 13582 & digitised from Atlas & $\begin{array}{l}\text { Puky, Schad and } \\
\text { Szövenyi, } 2006\end{array}$ \\
\hline Italy & $50 \times 50 \mathrm{~km}$ & 4292 & $\begin{array}{l}\text { provided by SHI (Societas } \\
\text { Herpetologica Italica) data } \\
\text { through R. Sindaco }\end{array}$ & Sindaco et al., 2006 \\
\hline Luxembourg & exact coordinates & 10642 & $\begin{array}{l}\text { provided by Musée National } \\
\text { d'Histoire Naturelle du } \\
\text { Luxembourg }\end{array}$ & Proess, 2003, 2007 \\
\hline Malta & $50 \times 50 \mathrm{~km}$ & 37 & compiled by Claudia Corti & \\
\hline Poland & $10 \times 10 \mathrm{~km}$ & 15502 & digitised from Atlas & $\begin{array}{l}\text { Głowaciński and Rafiński, } \\
2003\end{array}$ \\
\hline Portugal & $10 \times 10 \mathrm{~km}$ & 17431 & provided by A. Loureiro & Loureiro et al., 2010 \\
\hline Romania & exact coordinates & 5454 & provided by D. Cogălniceanu & $\begin{array}{l}\text { Cogălniceanu et al., } \\
\text { 2013a, 2013b }\end{array}$ \\
\hline Slovenia & $10 \times 10 \mathrm{~km}$ & 3414 & $\begin{array}{l}\text { provided by Societas Slovenica } \\
\text { Herpetologica }\end{array}$ & \\
\hline Spain & $10 \times 10 \mathrm{~km}$ & 68618 & $\begin{array}{l}\text { provided by Sociedad } \\
\text { Herpetológica Española }\end{array}$ & $\begin{array}{l}\text { Pleguezuelos, Lizana and } \\
\text { Márquez, 2002, updated } \\
\text { until } 2005\end{array}$ \\
\hline Sweden & exact coordinates & 30778 & obtained from GBIF & \\
\hline Switzerland & $10 \times 10 \mathrm{~km}$ & 5705 & $\begin{array}{l}\text { provided by Koordinationsstelle } \\
\text { für Amphibien- und } \\
\text { Reptilienschutz in der Schweiz } \\
\text { (KARCH) }\end{array}$ & Meyer et al., 2009 \\
\hline The Netherlands & $10 \times 10 \mathrm{~km}$ & 8061 & provided by RAVON & $\begin{array}{l}\text { Creemers and van Delft, } \\
2009\end{array}$ \\
\hline UK + Ireland & $10 \times 10 \mathrm{~km}$ & 20289 & digitised from Atlas & Arnold, 2005 \\
\hline Ukraine & $10 \times 10 \mathrm{~km}$ & 1162 & digitised from Atlas & $\begin{array}{l}\text { Kypnjehko and Bepbec, } \\
1999\end{array}$ \\
\hline Wallonia & $4 \times 4 \mathrm{~km}$ & 7269 & provided by Raînne-Natagora & Jacob et al., 2007 \\
\hline \multicolumn{5}{|l|}{ PERSONAL DATABASES } \\
\hline $\begin{array}{l}\text { J. Crnobrnja-Isailović, } \\
\text { D. Dobrnjić, } \\
\text { E. Tanović, } \\
\text { Idriz Haxhiu }\end{array}$ & $50 \times 50 \mathrm{~km}$ & 1128 & & \\
\hline P. de Pous & Several & 10405 & & \\
\hline D. Jablonski & $50 \times 50 \mathrm{~km}$ & 685 & & \\
\hline S.L. Kuzmin & $1^{\prime}$ & 17865 & & Kuzmin, 2013 \\
\hline
\end{tabular}


Table 1. (Continued.)

\begin{tabular}{lcclc}
\hline & Resolution & Records & Sources & Published atlases \\
\hline CONTINENTAL DATABASES & & & & Gasc et al., 1997 \\
$\quad$ Europe & $50 \times 50 \mathrm{~km}$ & 12155 & SEH & \\
GBIF & Several & 18772 & GBIF & \\
TOTAL & & 384609 & & \\
\hline
\end{tabular}

GPS point locality records). Therefore, the databases were homogenised, deleting all other information except species names, coordinates, and data source, and projected to the same coordinate system (WGS84).

\section{Map production}

As an atlas is usually the representation of the species' distributions by uniform units (Sillero, Celaya and MartínAlfageme, 2005; Loureiro and Sillero, 2010), record points were transformed into a grid. We used the official UTM grid of $50 \times 50 \mathrm{~km}$, that it is freely available from the European Environment Agency (http://www.eea.europa.eu/). This grid is based on the one used for the European Atlas of Flora, the first biological distribution atlas for Europe (Jalas and Suonuinen, 1972). It includes 4524 land squares. Therefore, each point database (COUNTRIES, SEH/GBIF, and INTRODUCED) was transformed to a grid file, by spatially overlapping with the $50 \times 50 \mathrm{~km}$ UTM grid. This transformation from the point databases (e.g. GPS points, as well as centroids of grids of $1 \times 1 \mathrm{~km}, 4 \times 4 \mathrm{~km}, 5 \times 5 \mathrm{~km}$, $10 \times 10 \mathrm{~km}$, and $50 \times 50 \mathrm{~km}$ squares) to a grid database was performed by a set of GIS scripts for ArcGIS 9.3 (see Supplementary table S1 online) in which for each species, each grid was assigned 0 for absence or 1 for presence.

The species maps (see example in fig. 1; all maps are provided online in Supplementary Atlases S1 and S2, and the corresponding GIS files in Supplementary Atlases S3 and S4; species codes are provided in Supplementary Atlas S5) were created automatically by overlapping the three grid files (COUNTRIES, SEH/GBIF, and INTRODUCED), using a script written in the R language (R 2.15, R Development Core Team, 2012). The script (included online in Supplementary Text S2) looked sequentially for each species in the three grids, representing them with different colours. The resulting maps were exported to images in .jpg format. Species richness maps for amphibians and reptiles were calculated by the sum of all species present in each grid cell. We then compared species richness maps with those based entirely on the original data of the 1997 European Atlas, and for each grid cell we subtracted the old from the new number of species occurring therein. The resulting value was subsequently represented on the same grid to indicate areas of increased vs. decreased quantity of recorded species. For a better cartographical representation, all maps are shown in the Albers Conical projection for Europe. This projection (EPSG code: 9822; http://spatialreference.org/ref/sr-org/44/ $\mathrm{html} /$ ) reduces cartographical distortions of Europe, by a better adjustment to the central meridian (Greenwich) and both standard parallels.

\section{Biogeographical analyses}

The coarse $50 \times 50 \mathrm{~km}$ occurrence data were not suitable for sophisticated analyses (e.g. calculation of ecological niche models; Sillero, 2011), and these were not the main goal of this compilation. We therefore did not apply any methods based on environmental niche modelling which at this level had already been carried out by Araújo, Thuiller and Pearson (2006) and Araújo et al. (2008). Instead, we used a number of descriptive statistics to visualise general biogeographic patterns. Besides calculating species richness, we also used clustering analysis to define chorotypes and applied a measure of regional endemism. Chorotypes were defined by Baroni-Urbani, Ruffo and Vigna Taglianti (1978) as clusters of species with statistically similar distributions for a specific area. However, Vigna-Taglianti et al. (1999) stated that to define chorotypes the whole species' distribution should be used. In fact, Vigna-Taglianti et al. (1999) proposed a standard classification of chorotypes using several groups of animals (e.g. beetles, amphibians, and reptiles). Nevertheless, the term chorotypes has been widely used when applied to the herpetofauna of certain regions (e.g. Corti et al., 1991, 1997; Olivero, Real and Márquez, 2011; Sillero et al., 2009, and reference therein). Our intention here was not to establish a standard classification of biogeographical regions for the European amphibians and reptiles, but to classify species by their distribution similarity using the current available knowledge. Notwithstanding this, and for avoiding misunderstandings, we will use the term distribution type instead of chorotype, proposed by Baroni-Urbani and Collinwood (1976) and Baroni-Urbani and Collinwood (1977). In these two works, distribution types were calculated using incomplete species' distributions.

Identification of the main distribution types of amphibians and reptiles in Europe was carried out following Sillero et al. (2009). The merged species distribution files (COUNTRIES and SEH/GBIF) were transformed into two separate data matrices for amphibians and reptiles, respectively (.csv format) and analysed using the R 2.15 software (R Development Core Team, 2012). Distribution types were determined by a Hierarchical Cluster Analysis using Jaccard's binary index and UPGMA as clustering method (Sillero et al., 2009), which is a measure of similarities among species distributions. This analysis was performed using the function "vegdist" of the R package "vegan" (Oksanen et al., 2012), which computes the Jaccard's index as $2 B=(1+B)$, where $B$ represents Bray-Curtis dissimilarity. The Bray- 


\section{Ichthyosaura alpestris}

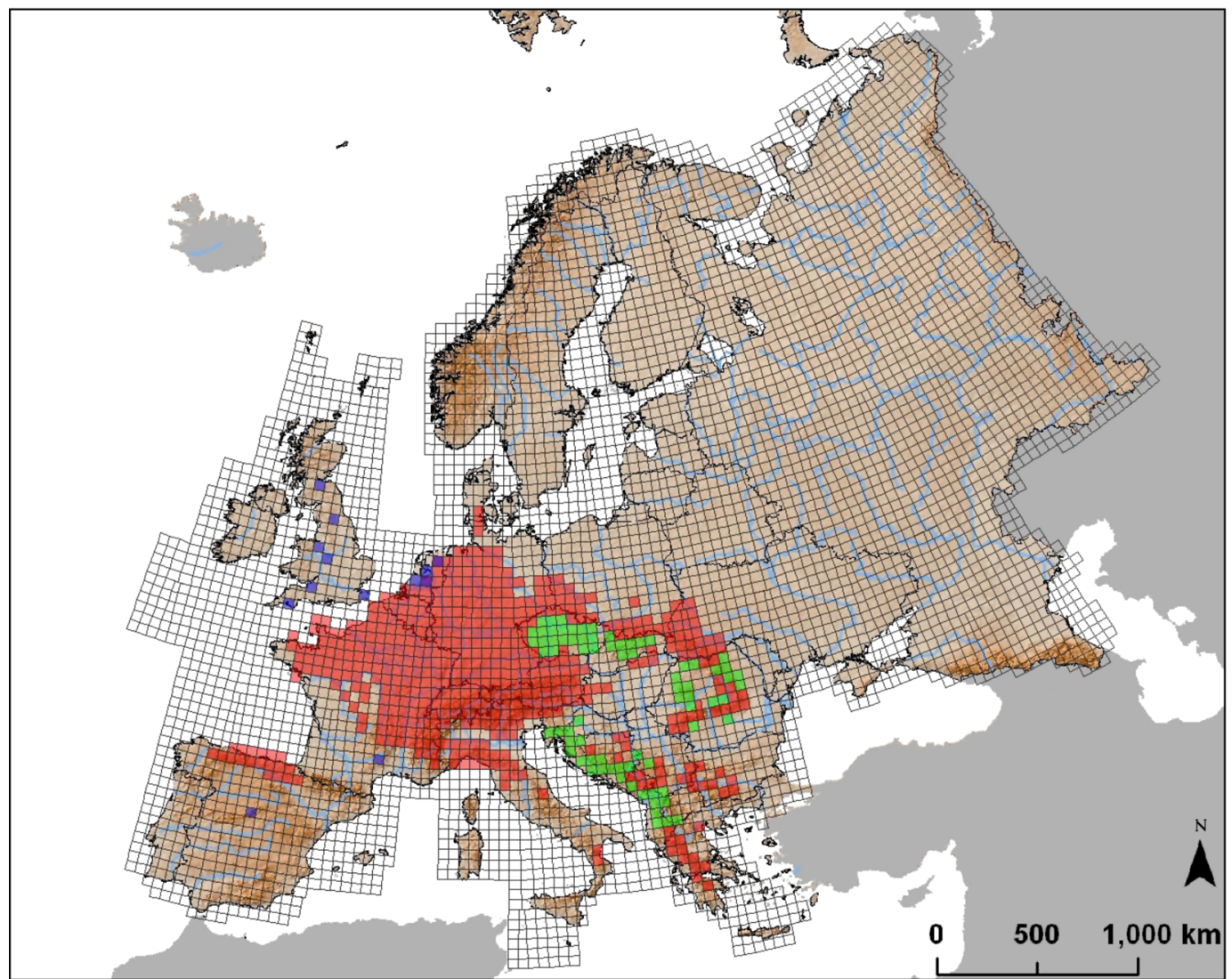

Figure 1. Example of species distribution map (Ichthyosaura alpestris) showing, in different colours, records corresponding to the COUNTRIES (red), SEH/GBIF (green) and INTRODUCED (purple) databases used in this study. Brown colours represent higher elevations. We used the official UTM grid of $50 \times 50 \mathrm{~km}$ from the European Environmental Agency (www.eea.europa.eu/). COUNTRIES database included data from published or on-going national atlases, and from personal data kindly provided to the SEH. SEH/GBIF included data from the 1997 European Atlas and the Global Information Facility (GBIF: www.gbif.org). We only included data from SEH/GBIF when data from COUNTRIES database were not available. Datasets for introduced species were not available in all countries.

Curtis dissimilarity is calculated as $(a+b-2 j) /(a+b)$, where $a$ and $b$ are the numbers of species on compared squares, and $j$ is the number of species in both squares compared. The Jaccard's index is 1 when species composition is identical between squares and 0 when two squares have no species in common. According to the values of Jaccard's index, the species were clustered into a dissimilarity tree, and the branches with a minimum of at least three species and splitting off the basal polytomy of this tree were defined as the main distribution types.

Using occurrence data of amphibians and reptiles, we separately calculated for the two groups the Corrected Weighted Endemism index (CWE) (Crisp et al., 2001). For calculating this index, the species are weighted by the inverse of their cell ranges so that species with narrow ranges are assigned relatively high weights, while species with broader ranges are assigned progressively lower weights
(Laffan and Crisp, 2003). The sum of the weighted values for a given cell (weighted endemism) is then divided by the number of species occurring in the cell. This correction for the cell species richness ensures that CWE values highlight areas with a high proportion of endemic species but not necessarily high in richness (Crisp et al., 2001; Laffan and Crisp, 2003; Laffan, Ramp and Roger, 2012). We calculated CWE using the "endemicity tools" extension for ArcView 3.2 (Danho, 2003), and performed computations at the cell level (radius = 1), excluding empty grid cells from analysis. Single cell calculations provide the maximum resolution for the analysis at the expense of artefacts occurring in poorly sampled cells (Laffan and Crisp, 2003). We assumed that herpetological explorations in Europe have been intensive enough to allow calculations at single-cell level (see below for a discussion of this assumption; see also Ficetola et al., 2013). 


\section{Results and discussion}

\section{Database compilation}

The COUNTRIES database includes a total of 364814 records; the SEH/GBIF database includes 15485 records; and the INTRODUCED database includes 4310 records. Our compilation thus totals 384609 entries from 28 national and personal databases, plus the original SEH and GBIF databases (table 1). The Spanish Herpetological Society provided the largest amount of records (68 618; updated until 2005; table 2). Other countries, like Portugal and Luxembourg also provided their entire database, with data about locality, author, and date. Records with a high spatial resolution (table 1 ) were also available for instance in Flanders $(5 \times 5 \mathrm{~km})$, Wallonia $(4 \times 4 \mathrm{~km})$, and Portugal (GPS points). Table 1 details the characteristics of the different databases that were used in this study. The final number of records per species represented in the $50 \times 50 \mathrm{~km}$ grids (total: 48440 occurrence records at the $50 \times 50 \mathrm{~km}$ grid level) is lower than in the sum of the three databases (COUNTRIES, SEH/GBIF, INTRODUCED) due to record duplications caused by the reduction in the spatial resolution of the UTM squares (e.g. from GPS points in the Portuguese database to the final $50 \times 50 \mathrm{~km}$ UTM square).

Overall, 218 taxa were mapped (73 species of amphibians and 145 of reptiles; table 3 ), including 13 amphibian and 18 reptile species that were not represented in the 1997 European Atlas (Gasc et al., 1997). However, as the study area is slightly different, 18 species from the eastern edges of the area covered by the 1997 European Atlas were not mapped in our compilation (see Study Area section). Therefore, and considering also taxonomical changes, our compilation includes 31 newly mapped species (table 3). We merged 46 taxa with others in the same species-level map (usually not more than 2-3 species per map) when their taxonomic status and/or their precise distribution boundaries were insufficiently known to warrant plotting
Table 2. Point records per country from the three main databases (COUNTRIES, SEH/GBIF, and INTRODUCED) of this compilation, for amphibians and reptiles, and for both groups together. See table 1 for number of records per national and personal databases.

\begin{tabular}{|c|c|c|c|}
\hline Country & Amphibians & Reptiles & $\begin{array}{l}\text { Amphibians } \\
\text { and reptiles }\end{array}$ \\
\hline Albania & 163 & 852 & 1015 \\
\hline Andorra & 12 & 23 & 35 \\
\hline Austria & 8365 & 5872 & 14237 \\
\hline Belgium* & 40413 & 4251 & 44664 \\
\hline $\begin{array}{l}\text { Bosnia and } \\
\text { Herzegovina }\end{array}$ & 177 & 312 & 489 \\
\hline Bulgaria & 1108 & 2565 & 3673 \\
\hline Belarus & 1258 & 195 & 1453 \\
\hline Croatia & 471 & 1924 & 2395 \\
\hline Czech Republic & 648 & 436 & 1084 \\
\hline Denmark & 3695 & 1452 & 5147 \\
\hline Estonia & 2525 & 480 & 3005 \\
\hline Finland & 1845 & 2264 & 4109 \\
\hline F.Y.R. of Macedonia & 74 & 201 & 275 \\
\hline France & 6865 & 5881 & 12746 \\
\hline Georgia & 742 & 18 & 760 \\
\hline Germany & 24380 & 11116 & 35496 \\
\hline Greece & 1430 & 11367 & 12797 \\
\hline Hungary & 8227 & 3738 & 11965 \\
\hline Ireland & 459 & 530 & 989 \\
\hline Italy & 1583 & 2736 & 4319 \\
\hline Latvia & 368 & 63 & 431 \\
\hline Liechtenstein & 8 & 5 & 13 \\
\hline Lithuania & 432 & 90 & 522 \\
\hline Luxembourg & 9539 & 1054 & 10593 \\
\hline Malta & 8 & 32 & 40 \\
\hline Moldova & 356 & 72 & 428 \\
\hline Montenegro & 94 & 228 & 322 \\
\hline Netherlands & 6249 & 2012 & 8261 \\
\hline Norway & 6958 & 3359 & 10317 \\
\hline Poland & 11264 & 4127 & 15391 \\
\hline Portugal & 8054 & 9101 & 17155 \\
\hline Romania & 3084 & 4470 & 7554 \\
\hline Russia & 14315 & 2695 & 17010 \\
\hline Serbia & 493 & 721 & 1214 \\
\hline Slovakia & 1694 & 641 & 2335 \\
\hline Slovenia & 1522 & 1489 & 3011 \\
\hline Spain & 27797 & 41059 & 68856 \\
\hline Sweden & 26562 & 4253 & 30815 \\
\hline Switzerland & 3015 & 2464 & 5479 \\
\hline Ukraine & 4031 & 881 & 4912 \\
\hline United Kingdom & 10880 & 8417 & 19297 \\
\hline TOTAL & 241163 & 143446 & 384609 \\
\hline
\end{tabular}

* Belgium data was composed by three different databases: Flanders, Wallonia, and Brussels.

them on separate maps (see section on taxonomic gaps of knowledge below and table 3 ). 


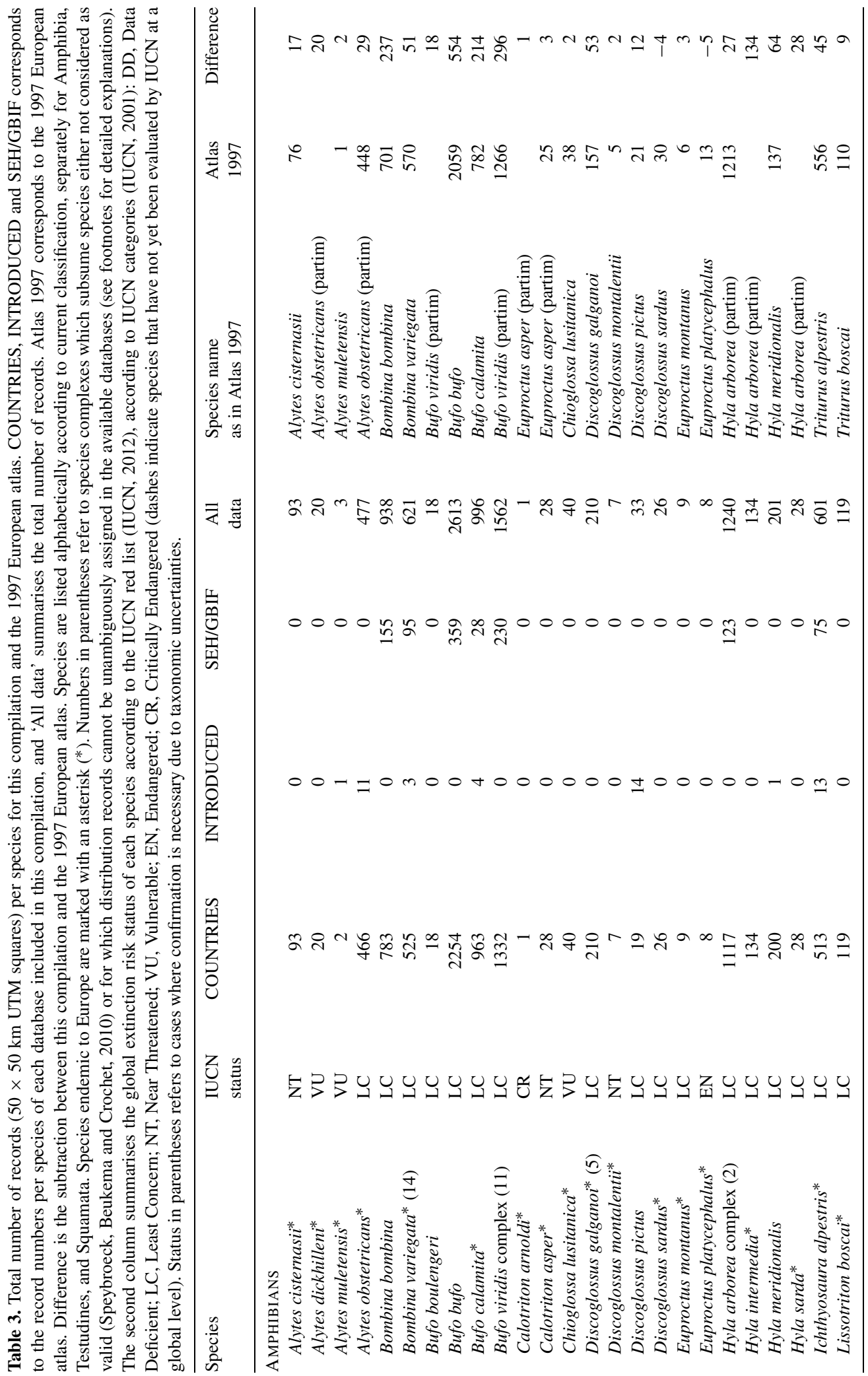




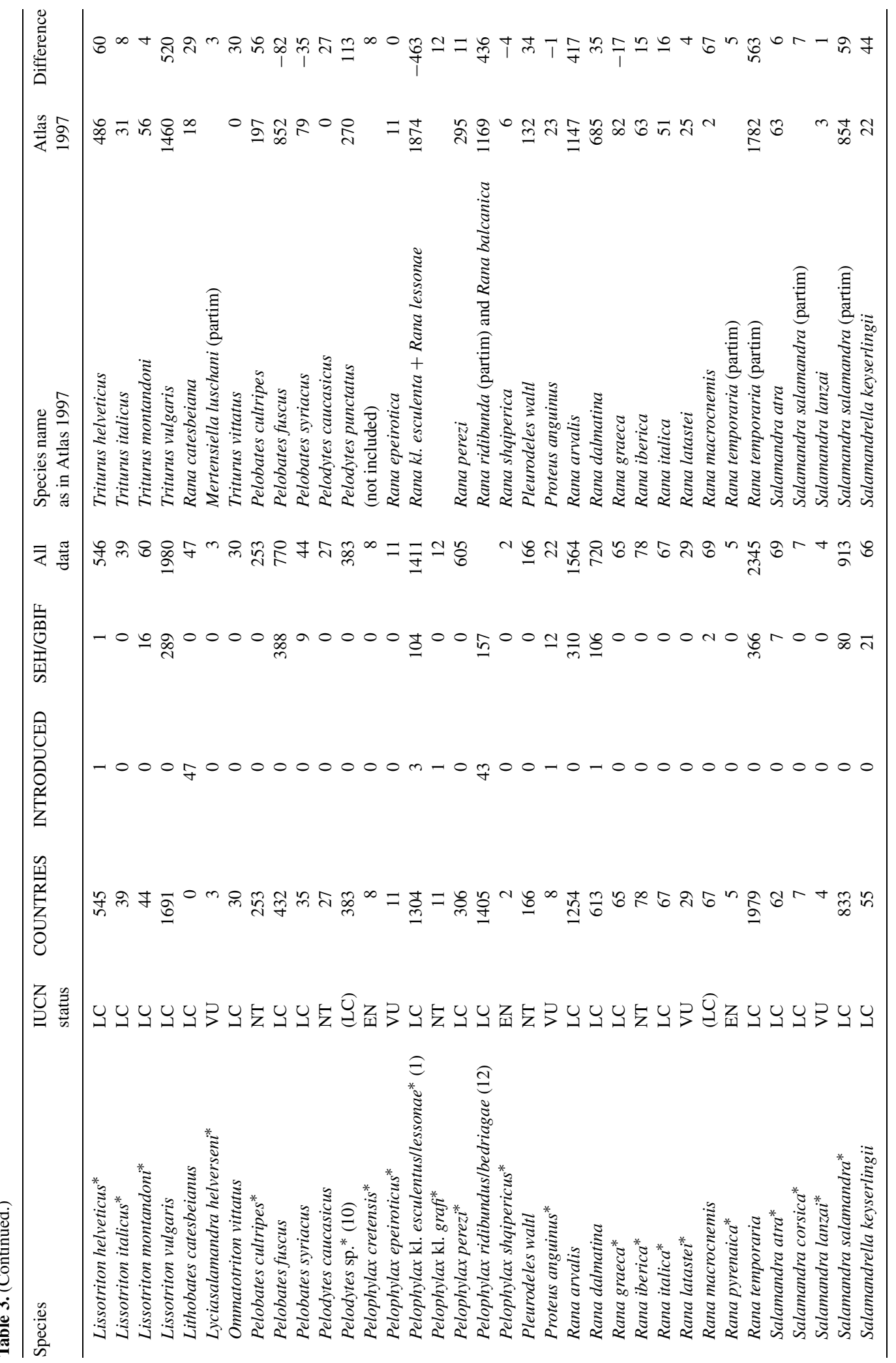




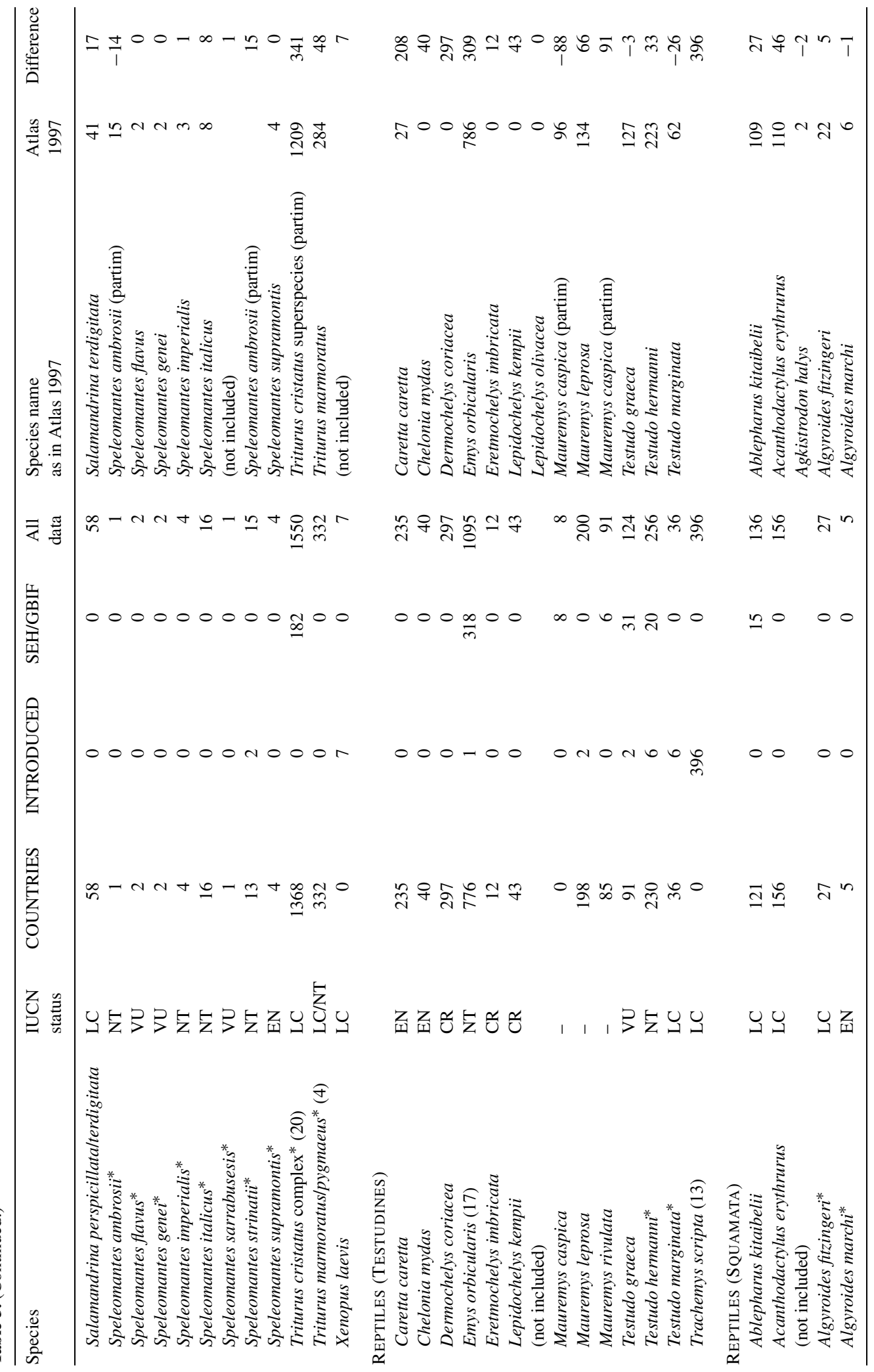




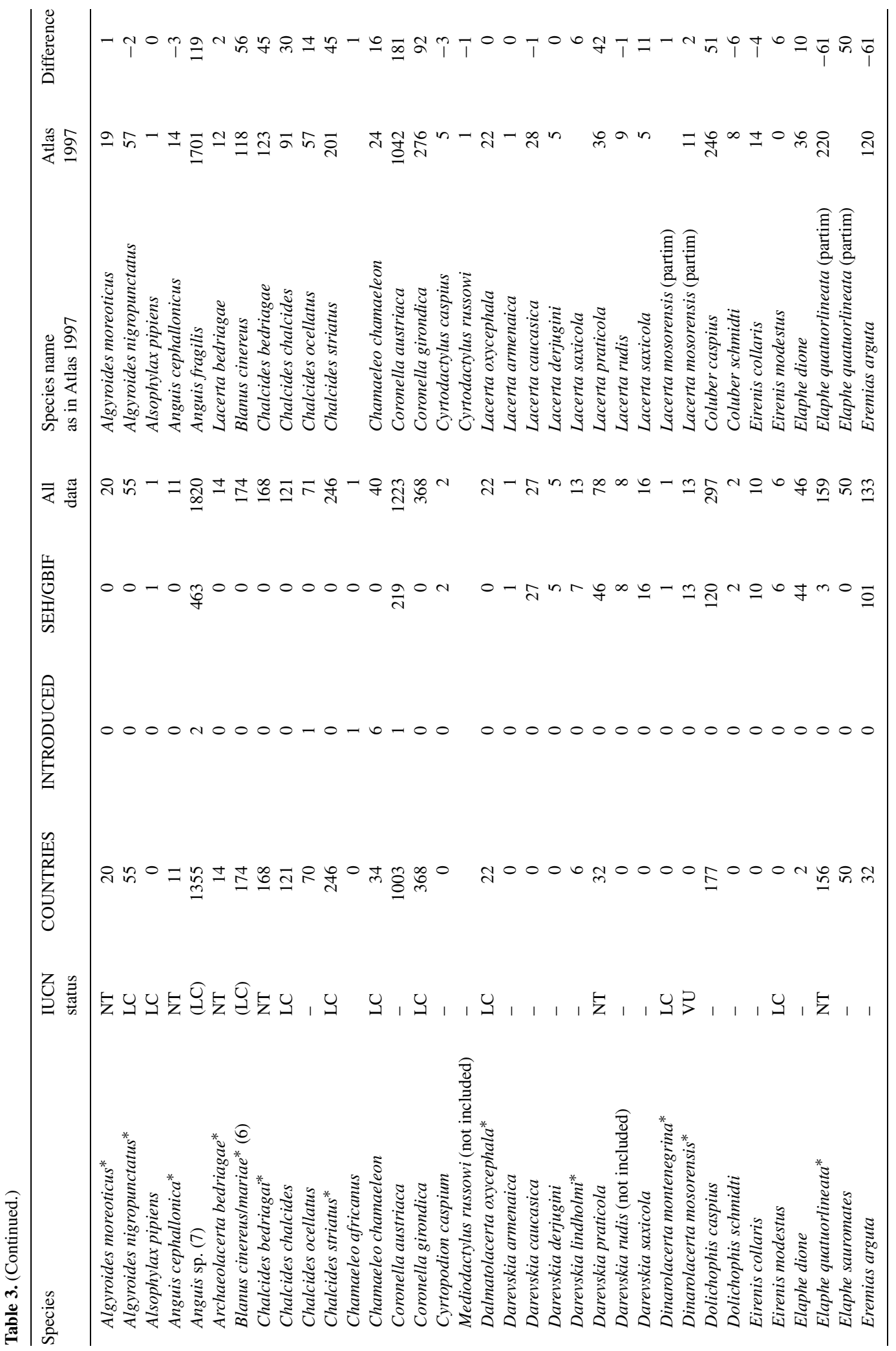




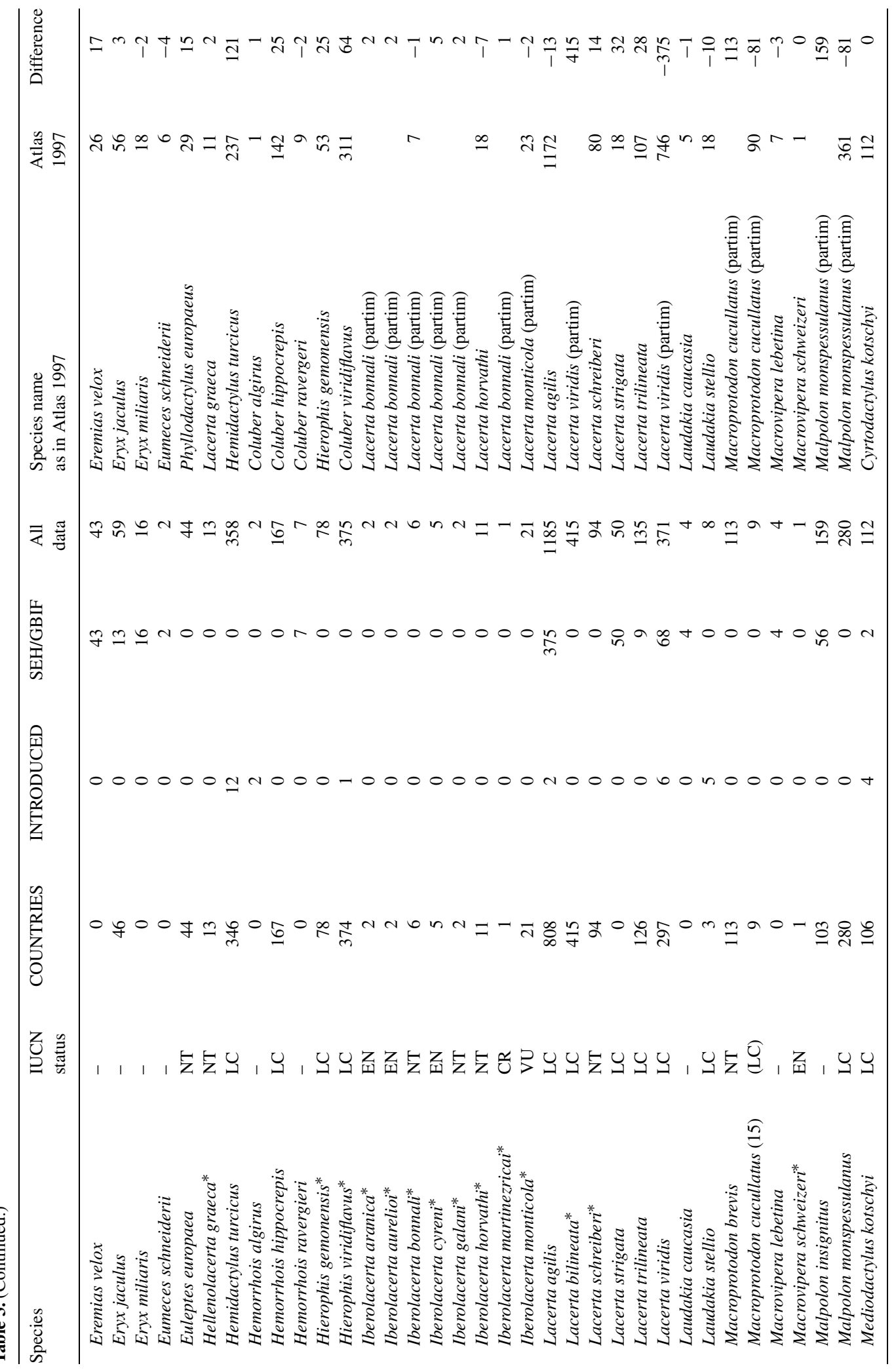




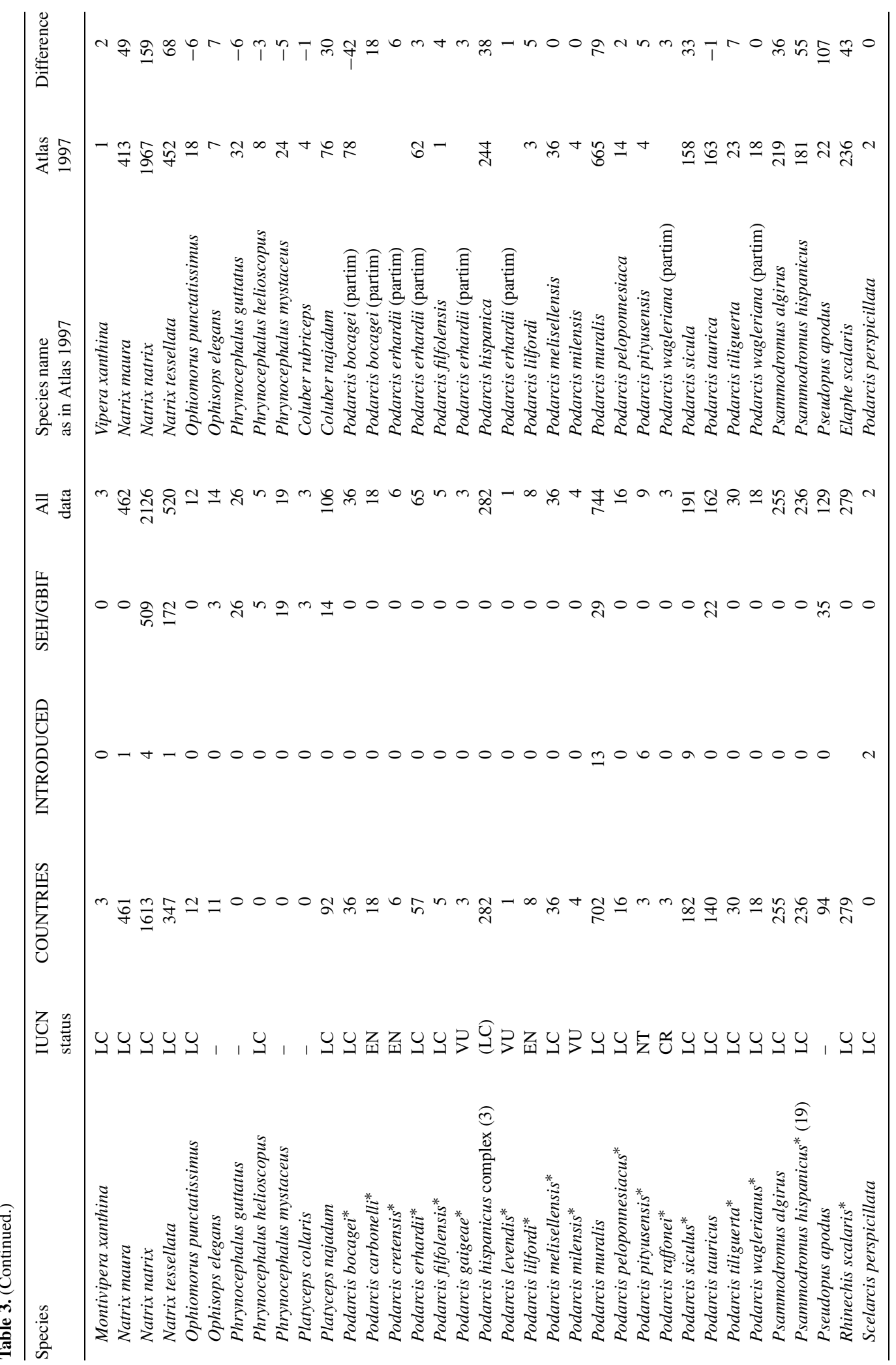




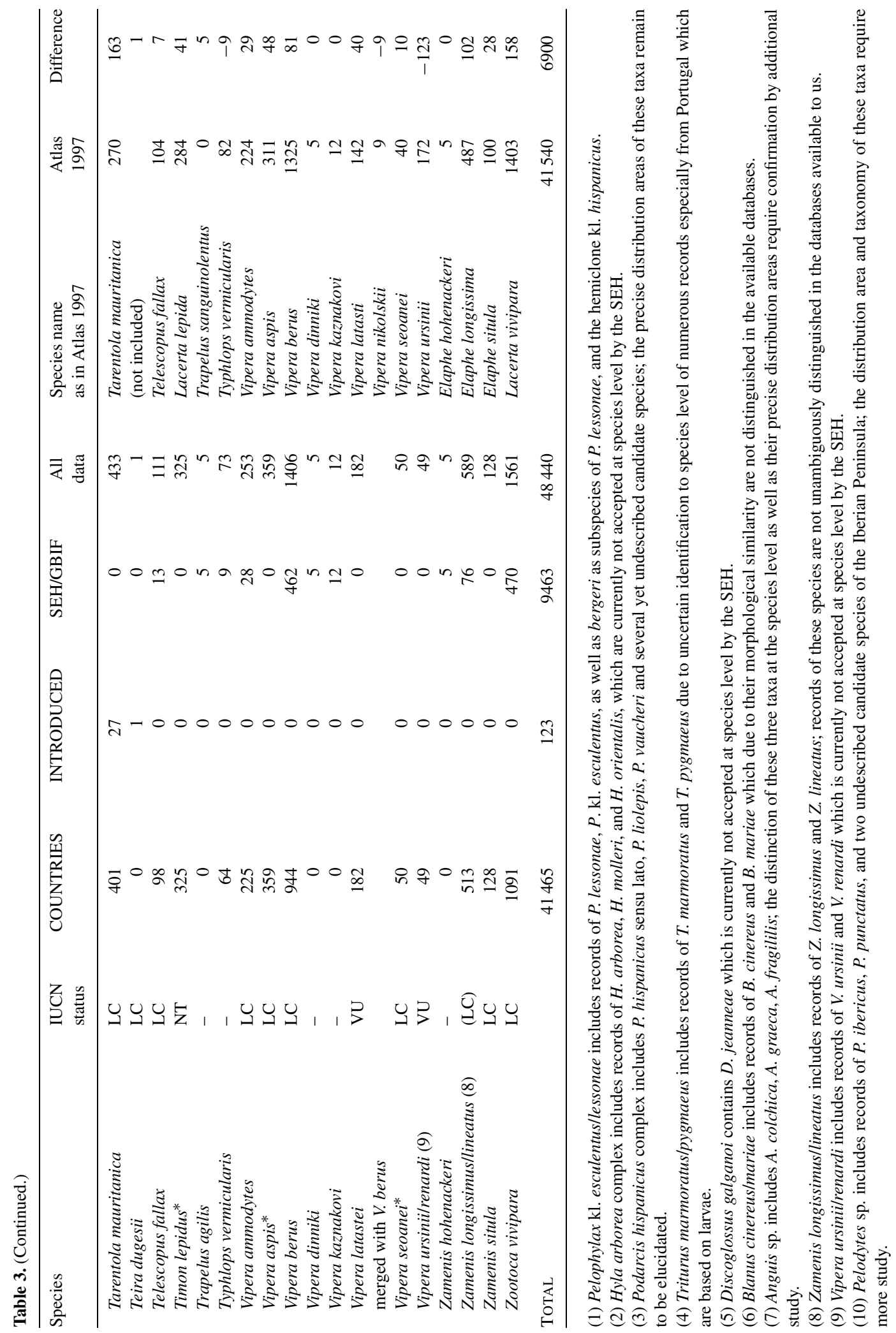




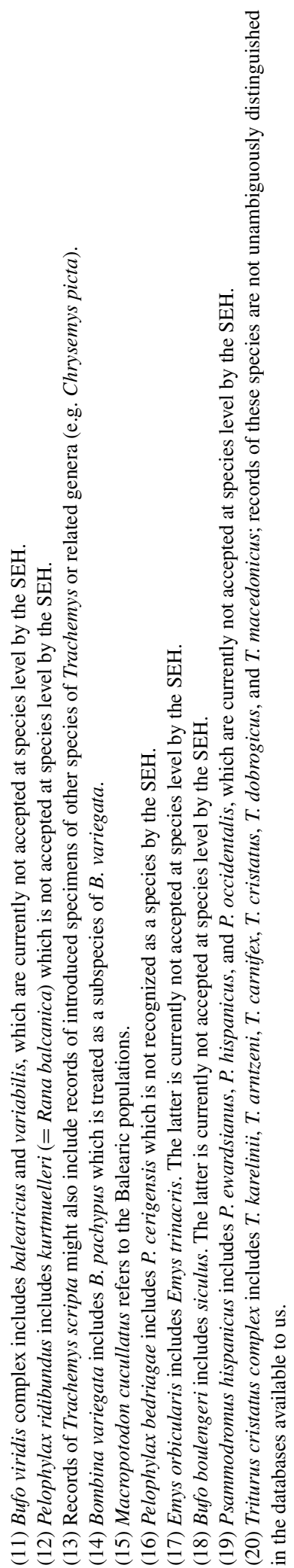

Nine species (six amphibians and three reptiles) represented more than 10000 records in the whole compiled point databases, corresponding in almost all cases to the most widespread species in Europe. From lesser (11 696) to larger (31 638), these were: Zootoca vivipara, Anguis sp., Ichthyosaura alpestris, Natrix natrix, Triturus cristatus complex, Pelophylax kl. esculentus/lessonae, Lissotriton vulgaris, Rana temporaria, and Bufo bufo. In the opposite extreme, there were 41 species (13 amphibians and 28 reptiles) with less than 10 records. These species corresponded to endemisms of mainland Europe (e.g. Iberolacerta aranica) and of the Mediterranean islands (e.g. Podarcis filfolensis). However, and particularly for the most widespread taxa, the higher number of records also correspond to species present in distribution atlases with a high resolution, i.e. a high number of records. In relation with the whole database in grid format (table 3), 16 species included more than 1000 records (i.e. present in more than 1000 grid cells), three of them with more than 2000 (i.e., Natrix natrix, Rana temporaria, Bufo bufo). All these, again, were species widespread in Europe. On the other hand, 59 species were present in less than 10 cells, many of them endemisms (e.g. Podarcis levendis), but others were marginal species with their main distribution range outside the study area (e.g. Eirenis modestus).

The increment in distribution knowledge was considerable (4224 new grid records, 19.6\%). Although the taxa entities are not completely congruent, $44(8.3 \%)$ taxa presented less records than in the 1997 European Atlas; 17 (7.8\%) the same number; and 152 (69.7\%) more records (table 3). The extremes are Pelophylax kl. esculentus/lessonae with a loss of 463 records, and Rana temporaria with a gain of 563 records. The reasons for the changes in the number of grid cells per species are manifold. Increases are usually due to an improved mapping intensity and coverage, whereas decreases are often explained by changes in taxonomy such as splitting of previously widespread species into dif- 
ferent species, or redefinitions of taxa with corresponding reduction of their actual ranges, but also because of the low number of recent data for some countries devoid of distribution atlas programs (see table 1).

Patterns of species richness were different in amphibians and reptiles as we will further explore in the biogeography section below. Species richness of amphibians was highest in Western-Central Europe, while for reptiles the southern peninsulas had the highest concentration of species, in particular Greece (fig. 2), which is in general agreement with analyses based on the 1997 European Atlas (Araújo, Thuiller and Pearson, 2006; Araújo et al., 2008) and the Global Amphibian Assessment (e.g. Anthony et al., 2008; Baha el Din et al., 2008). Several countries such as Albania, Bosnia and Herzegovina, Latvia, Lithuania, Ireland, F.Y.R. of Macedonia, Moldova, Montenegro and Serbia presented low levels of species richness, mainly due to insufficient coverage, impossibility of digitising chorological information published in journals, or because database chairs decided not to collaborate in our compilation. No atlases or articles with chorological data are currently available for some of these countries, as far as we know. Calculating species richness for endemic European species only (i.e. excluding all species which have ranges extending outside the study area) leads to a strong shift of species richness towards Western Europe, reflecting that the Balkan Peninsula holds many species with ranges extending into the Middle East and Caucasus, and Central Europe holds many widespread species with ranges extending east of the Ural Mountains (fig. 3). Similarly, the Caucasus region was not identified as an area of endemism because most of the numerous species endemic to the Caucasus Mountains are distributed on the southern slopes as well, i.e. outside Europe as we defined it.

The species richness of European threatened amphibians, following the IUCN categories Vulnerable (VU), Endangered (EN), and Critically Endangered (CR), presented a very patchy distribution (fig. 4): north-western Iberian Peninsula, Po lowland, Sardinia, and western Greek coast were the areas with a higher number of threatened amphibians. On the other hand, threatened reptiles were widespread, especially in the Iberian and Italian peninsulas as well as in Central Europe. These different patterns are due to the species composition: threatened amphibians were mostly composed by localised endemics (e.g. Alytes muletensis) while threatened reptiles included some widespread species (e.g. Emys orbicularis). However, the European herpetofauna might have a higher level of conservation threat than currently recognised (Denoël, 2012). Future evaluations such as those provided through herpetological atlases could thus shed light on wider patterns of vulnerability (see e.g. Denoël, 2012).

\section{Biogeographical analysis}

The analysis of corrected weighted endemism (CWE) highlighted the importance of Mediterranean islands as centres of endemism for both amphibians and reptiles (fig. 5). For amphibians, highest CWE values were found in Sardinia and Corsica, Mallorca, Sicily, and southern Aegean islands. In addition, some grid cells on the Balkans and the Western Caucasus stand out with high local endemism values. Reptiles showed an overall similar pattern, but some areas such as Corsica, Sicily and the southern Aegean presented lower CWE values while additional areas of endemism were identified on smaller Mediterranean islands such as Malta, as well as certain areas in Spain (corresponding to the microendemic Iberolacerta species) and the Balkans.

However, these CWE calculations were somewhat biased due to our definition of the study area. Because the CWE calculation took the full range size of a species into account, and the full range sizes of some species (104) were not included in the study area (and thus not complete in the compilation database used for analysis, especially regarding species distributed in 


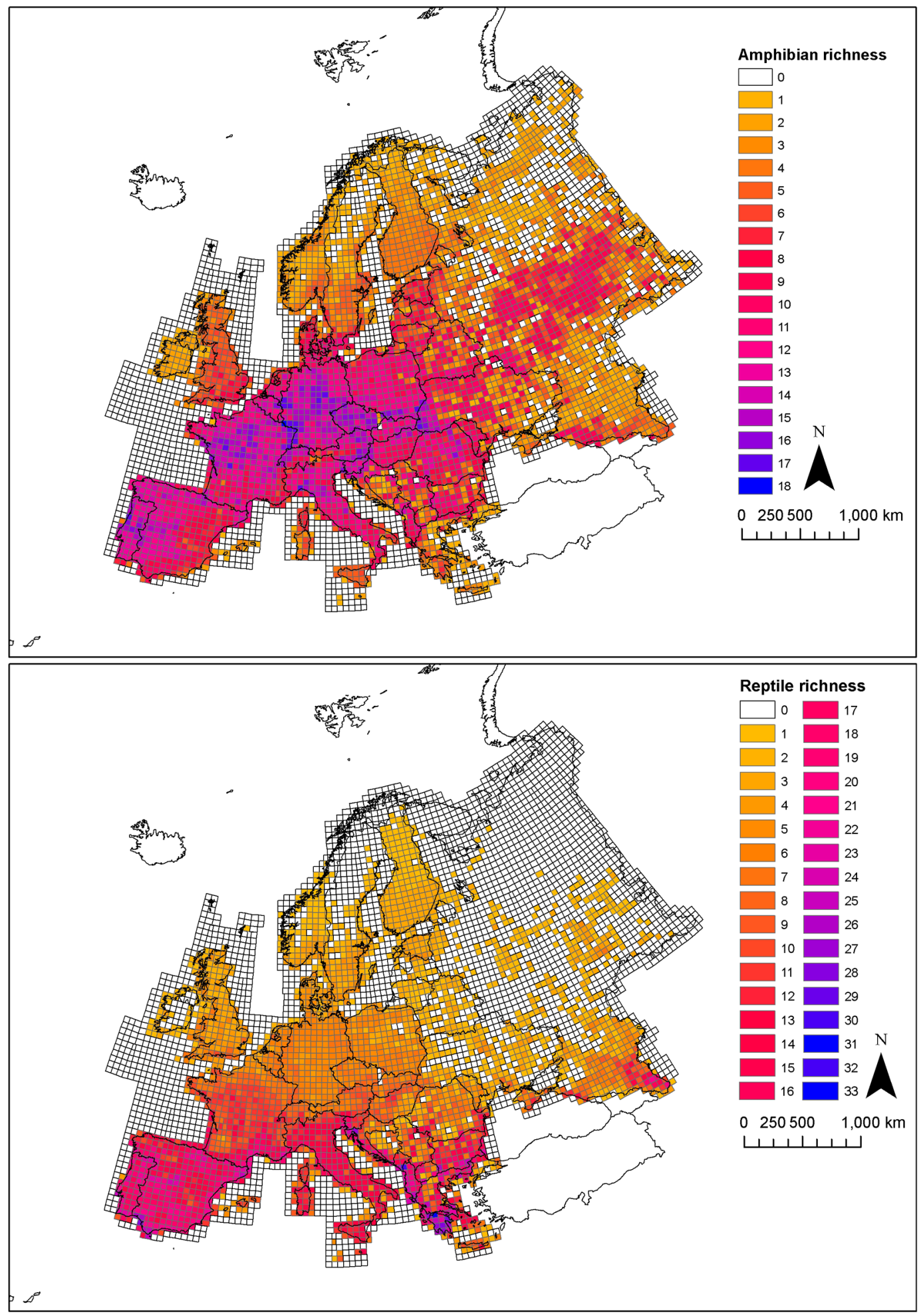

Figure 2. Maps of Europe showing species richness separately for amphibians and reptiles, based on species distribution maps of all non-introduced species occurring in the study area. 


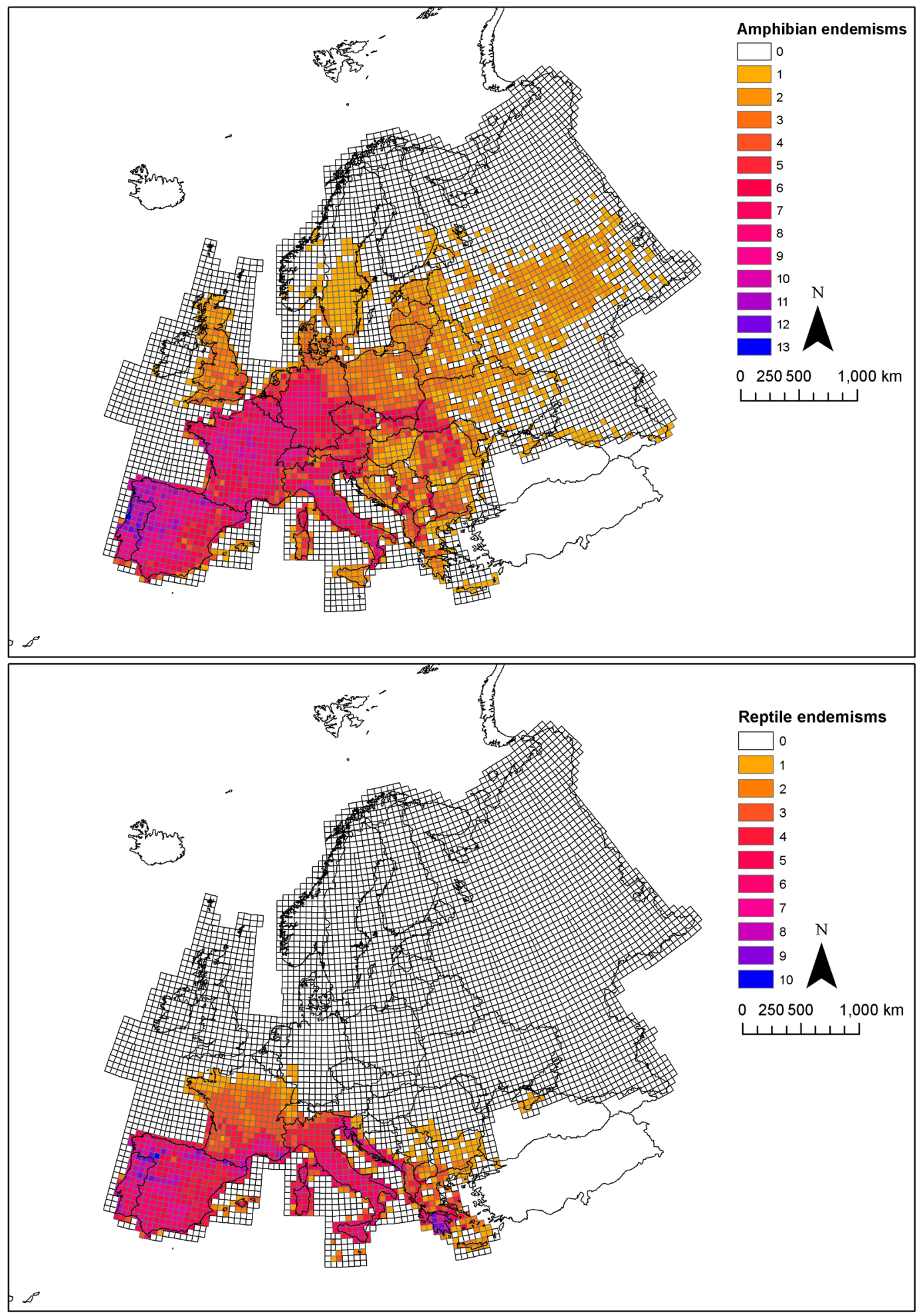

Figure 3. Maps of Europe showing species richness based on species distribution maps of European endemic amphibians and reptiles (i.e. including only species whose range does not extend beyond the study area). 


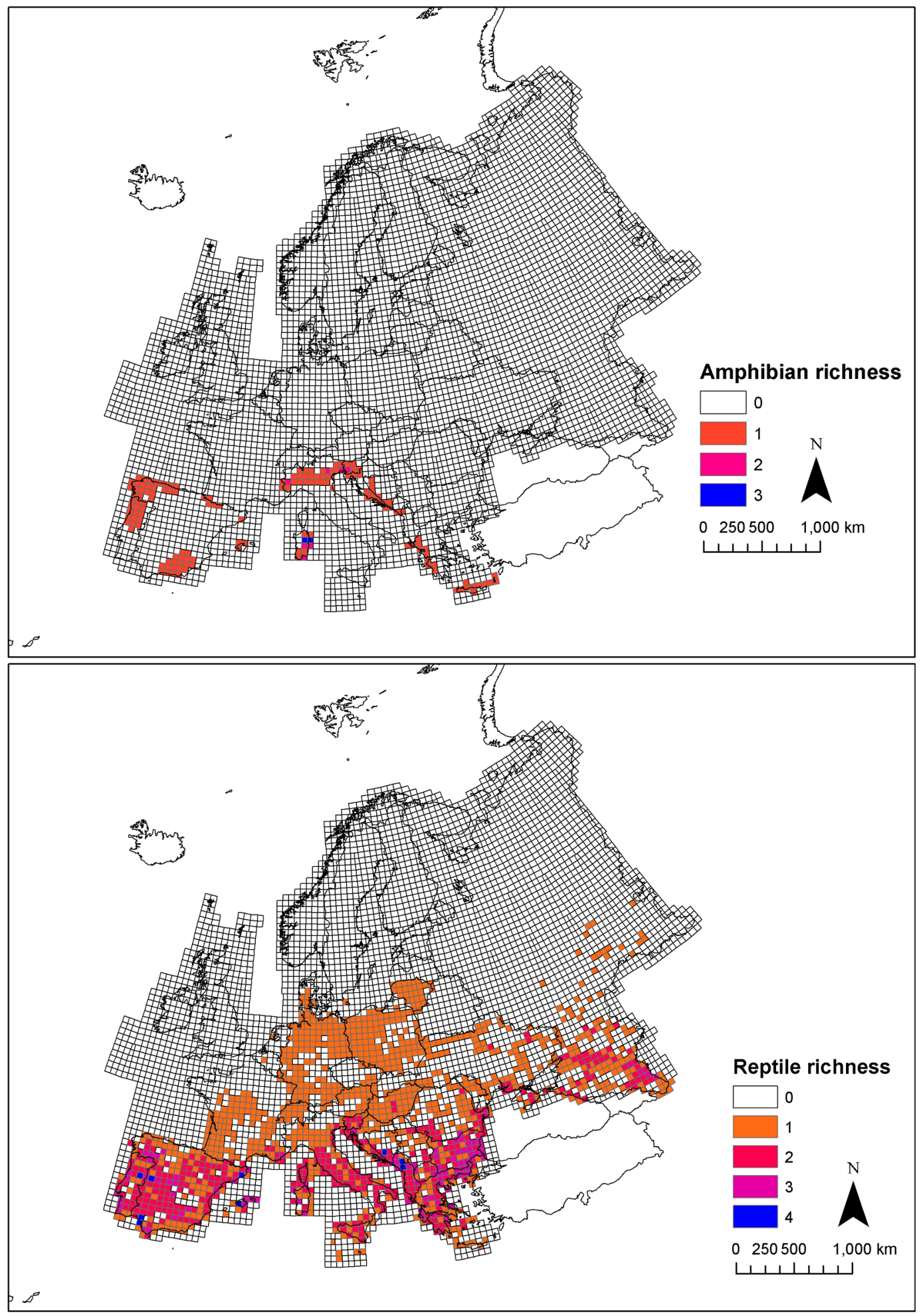

Figure 4. Maps of Europe showing species richness based on species distribution maps of European threatened amphibians and reptiles, including the IUCN categories Vulnerable, Endangered, and Critically Endangered. 


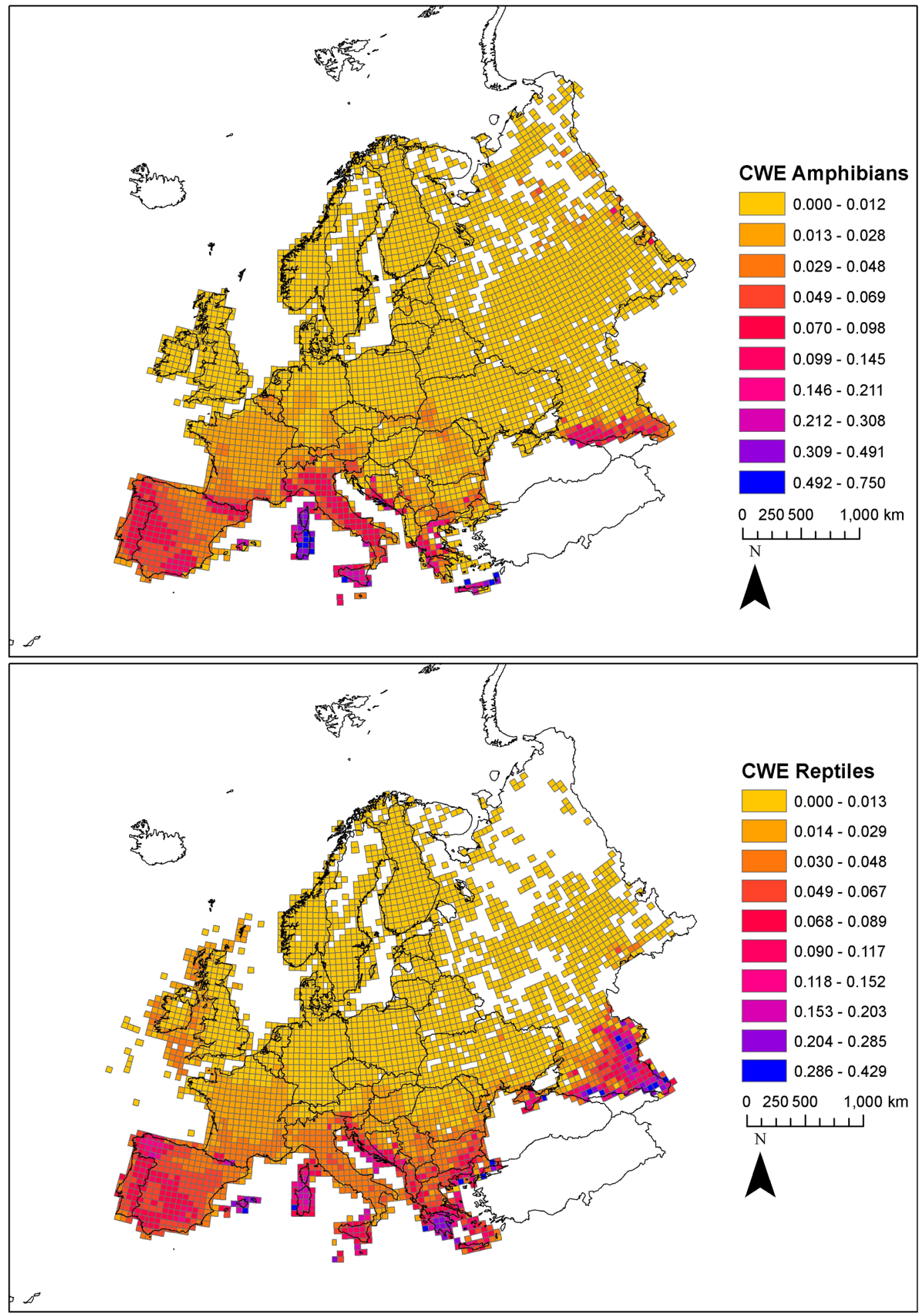

Figure 5. Maps of Europe showing Corrected Weighted Endemism (CWE) based on species distribution maps of European endemic amphibians and reptiles. 
the Balkan Peninsula or widespread in Central Europe), it is possible that CWE values in the eastern part of Europe were slightly inflated. In other words, many species occur in just a small part of the study area and thus appear to be range-restricted and micro-endemic, while in fact they have wide ranges extending further east outside our study area. This phenomenon is inversely analogous to the species richness patterns of endemic European amphibians, where the same artefacts lead to inflated species richness values in Western Europe. These problems call for caution in interpreting the biogeographic analysis of our data, but do not invalidate the observed general patterns. Furthermore, from the point of view of conservation priorities, the observed patterns of Europe-endemic species richness are highly relevant since they highlight the importance of specific areas (especially the Mediterranean islands), where the survival of a large number of European endemics fully depends on European conservation efforts.
Nine and 13 main distribution types were identified for amphibians (named CA1-CA9; table 4 and online Supplementary fig. S2) and reptiles respectively (named CR1-CR13; table 5 and online Supplementary fig. S3). Many species that formed clusters of only one member, corresponding mainly to regional endemics, were not assigned to a distribution type number and are not further considered here. In the following, we will briefly characterise distribution types and mention one representative species for each. Amphibian distribution types can be characterised as follows (table 4 and online Supplementary fig. S2): CA1, species distributed in the Iberian Peninsula and western France (e.g. Hyla meridionalis); CA2, western European species (e.g. Alytes obstetricans); CA3, species widespread in Europe (e.g. Bufo bufo); CA4, Pyrenaean species (e.g. Calotriton asper); CA5 and CA6, species distributed in Corsica, Sardinia, and the southern Mediterranean coast (e.g. Euproctus platycephalus, CA5; and Discoglossus sardus, CA6); CA7, species from the Italian Penin-

Table 4. Amphibian species grouped by main distribution types. See the dendrogram in online Supplementary fig. S1. Distribution types were named with codes following Baroni-Urbani and Collingwood (1976) and Baroni-Urbani and Collingwood (1977).

\begin{tabular}{l}
\hline Distribution type CA1 \\
\hline Alytes cisternasii \\
Chioglossa lusitanica \\
Discoglossus galganoi \\
Hyla meridionalis \\
Lissotriton boscai \\
Pelobates cultripes \\
Pelodytes sp. \\
Pelophylax perezi \\
Pleurodeles waltl \\
Rana iberica \\
Triturus marmoratus/pygmaeus \\
\hline Distribution type CA2 \\
\hline Alytes obstetricans \\
Bombina variegata \\
Bufo calamita \\
Hyla arborea complex \\
Ichthyosaura alpestris \\
Lissotriton helveticus \\
Salamandra salamandra \\
Rana dalmatina
\end{tabular}

\begin{tabular}{l}
\hline Distribution type CA3 \\
\hline Bombina bombina \\
Bufo bufo \\
Bufo viridis \\
Lissotriton montandoni \\
Lissotriton vulgaris \\
Pelobates fuscus \\
Pelophylax kl. esculentus/lessonae \\
Pelophylax ridibundus \\
Rana arvalis \\
Rana temporaria \\
Triturus cristatus complex \\
\hline Distribution type CA4 \\
\hline Calotriton asper \\
Pelophylax kl. grafi \\
Rana pyrenaica \\
\hline Distribution type CA5 \\
\hline Discoglossus sardus \\
Euproctus montanus \\
Hyla sarda \\
Discoglossus montalenti \\
Salamandra corsica
\end{tabular}

\begin{tabular}{l}
\hline Distribution type CA6 \\
\hline Euproctus platycephalus \\
Speleomantes flavus \\
Speleomantes supramontis \\
\hline Distribution type CA7 \\
\hline Hyla intermedia \\
Rana italica \\
Salamandrina \\
perspicillatalterdigitata \\
Speleomantes italicus \\
Lissotriton italicus \\
\hline Distribution type CA8 \\
\hline Ommatotriton vittatus \\
Pelodytes caucasicus \\
Rana camerani \\
\hline
\end{tabular}

Distribution type CA9

Proteus anguinus

Rana latastei

Salamandra atra 
Table 5. Reptile species grouped by main distribution types. See dendrogram in online Supplementary fig. S2. Distribution types were named with codes following Baroni-Urbani and Collingwood (1976) and Baroni-Urbani and Collingwood (1977).

\begin{tabular}{l}
\hline Distribution type CR1 \\
\hline Ablepharus kitaibelii \\
Darevskia praticola \\
Dolichophis caspius \\
Elaphe sauromates \\
Lacerta viridis \\
Montivipera xanthina \\
Natrix tessellata \\
Ophisops elegans \\
Podarcis tauricus \\
Testudo graeca \\
Vipera ammodytes \\
\hline Distribution type CR2 \\
\hline Acanthodactylus erythrurus \\
Blanus sp. \\
Chalcides bedriagae \\
Chalcides striatus \\
Chamaeleo chamaeleon \\
Coronella girondica \\
Hemidactylus turcicus \\
Hemorrhois hippocrepis \\
Macroprotodon brevis \\
Malpolon monspessulanus \\
Mauremys leprosa \\
Natrix maura \\
Podarcis hispanicus complex \\
Psammodromus algirus \\
Psammodromus hispanicus complex \\
Rhinechis scalaris \\
Tarentola mauritanica \\
Timon lepidus \\
Vipera latastei \\
\hline Distibution type CR3 \\
\hline tom
\end{tabular}

\section{Distribution type CR3}

Algyroides fitzingeri

Archaeolacerta bedriagae

Euleptes europea

Podarcis tiliguerta

\begin{tabular}{|c|}
\hline Distribution type CR4 \\
\hline $\begin{array}{l}\text { Algyroides moreoticus } \\
\text { Anguis cephalonica } \\
\text { Eryx jaculus } \\
\text { Hellenolacerta graeca } \\
\text { Hierophis gemonensis } \\
\text { Lacerta trilineata } \\
\text { Malpolon insignitus } \\
\text { Mauremys rivulata } \\
\text { Mediodactylus kotschyi } \\
\text { Ophiomorus punctatissimus } \\
\text { Platyceps najadum } \\
\text { Podarcis erhardii } \\
\text { Podarcis peloponnesiacus } \\
\text { Pseudopus apodus } \\
\text { Telescopus fallax } \\
\text { Testudo marginata } \\
\text { Typhlops vermicularis } \\
\text { Zamenis situla } \\
\end{array}$ \\
\hline Distribution type CR5 \\
\hline $\begin{array}{l}\text { Algyroides nigropunctatus } \\
\text { Dalmatolacerta oxycephalus } \\
\text { Dinarolacerta mosorensis } \\
\text { Podarcis melisellensis } \\
\end{array}$ \\
\hline Distribution type CR6 \\
\hline $\begin{array}{l}\text { Anguis sp. } \\
\text { Coronella austriaca } \\
\text { Emys orbicularis } \\
\text { Lacerta agilis } \\
\text { Natrix natrix } \\
\text { Vipera berus } \\
\text { Zootoca vivipara }\end{array}$ \\
\hline Distribution type CR7 \\
\hline $\begin{array}{l}\text { Chalcides chalcides } \\
\text { Elaphe quatorlineata } \\
\text { Hierophis viridiflavus } \\
\text { Lacerta bilineata } \\
\text { Podarcis muralis } \\
\text { Podarcis sicula } \\
\text { Testudo hermanni } \\
\text { Vipera aspis } \\
\text { Zamenis longissimus/lineatus }\end{array}$ \\
\hline
\end{tabular}

\begin{tabular}{l}
\hline Distribution type CR8 \\
\hline Darevskia caucasica \\
Eirenis collaris \\
Eirenis modestus \\
Hemorrhois ravergieri \\
Laudakia caucasia \\
\hline Distribution type CR9 \\
\hline Darevskia derjurgini \\
Darevskia saxicola \\
Vipera kaznakovi \\
\hline Distribution type CR10 \\
\hline Dolichophis schmidtii \\
Eumeces schneiderii \\
Macrovipera lebetina \\
Mauremys caspica \\
\hline
\end{tabular}

Distribution type CR11

Elaphe dione

Eremias arguta

Eremias velox

Eryx miliaris

Lacerta strigata

Phrynocephalus guttatus

Phrynocephalus mystaceus

Trapelus agilis

Vipera ursinii/renardi

Distribution type CR12

Iberolacerta aranica

Iberolacerta aurelioi

Iberolacerta bonnali

Distribution type CR13

Iberolacerta galani

Iberolacerta martinezricai

Iberolacerta monticola

Lacerta schreiberi

Podarcis bocagei

Podarcis carbonelli

Vipera seoanei sula (e.g. Hyla intermedia); CA8, Caucasian species (e.g. Pelodytes caucasicus); and CA9, alpine and dinaric species (e.g. Salamandra atra). In the case of reptiles (table 5 and online Supplementary fig. S3): CR1, species distributed along the Italian and Balkan Peninsulas as well as south-eastern Europe (e.g. Natrix tessellata); CR2 grouped species distributed along the western-southern Mediter- ranean countries (e.g. Malpolon monspessulanus); CR3, Corsican and Sardinian species (e.g. Archaeolacerta bedriagae); CR4, species from the Balkan Peninsula and Eastern Europe (e.g. Malpolon insignitus); CR5, species from the eastern Adriatic coast (e.g. Podarcis melisellensis); CR6, widespread in all of $\mathrm{Eu}-$ rope (e.g. Anguis sp.); CR7, western-central European species (e.g. Vipera aspis); CR8, CR9, 
and CR10, Caucasian species (e.g. Darevskia caucasica, CR8; Vipera kaznakovi, CR9; Mauremys caspica, CR10); CR11, South-eastern European species (e.g. Eremias velox); CR12, species from the Central Pyrenees (e.g. Iberolacerta bonnali); and CR13, species occurring in the north-western Iberian Peninsula (e.g. $\mathbf{L a}$ certa schreiberi).

These distribution types were partly but not fully congruent with those published for a more limited study area (i.e. the Iberian Peninsula; Sillero et al., 2009). The discordances can be explained by a higher number of species included in the present analysis, a larger size of the study area, and a different spatial resolution of the grid. As Europe holds more species and is considerably larger than the Iberian Peninsula, the resulting main distribution types at least partially included the Iberian distribution types. The definition and interpretation of distribution types is always relative and strongly depends on the study area.

The distribution types defined in this work for European amphibians and reptiles are not in full agreement with previous biogeographical classifications, because our classification was based on the distribution of species (always incomplete) and not on environmental data (Bunce et al., 2002) or distribution data from herpetological guide books (e.g. range polygons on continental maps; Rueda, Rodríguez and Hawkins, 2010). Bunce et al. (2002) defined 59 environmental classes based in a grid square of $0.5 \mathrm{~min}$ (i.e. ca. $55 \mathrm{~km}$ ). As Bunce et al. (2002) did not provide a hierarchical tree of environmental classes, only some of these classes had correspondence with our distribution types (e.g. CR6 and CR13). Rueda, Rodríguez and Hawkins (2010) identified respectively seven and eight biogeographical regions for amphibians and reptiles in Europe. In the case of amphibians, Rueda, Rodríguez and Hawkins (2010) clustered the distribution types CA 8 and CA9 in one single region. In reptiles, the distribution types including species for the three Mediterranean peninsulas (CR4 and CR7) are also considered by Rueda, Rodríguez and Hawkins (2010). No widespread species (e.g. Bufo bufo or Vipera berus) fit in any of the regions identified by Bunce et al. (2002) or Rueda, Rodríguez and Hawkins (2010).

\section{Taxonomic and mapping gaps of knowledge}

About ten species-level units in our analysis are characterised by taxonomic uncertainty or by difficulties in species identification; some of these are (or might be) composed of different taxa (see footnotes in table 3). Particular taxonomic efforts are needed to clarify both the status and the precise distribution limits of the Bufo viridis complex (balearicus, variabilis, viridis), the Hyla arborea complex ( $H$. arborea, $H$. molleri, and $H$. orientalis), Iberian Pelodytes (P. ibericus, P. punctatus, and two yet undescribed candidate species), the Anguis fragilis complex (A. colchica, A. graeca, A. fragilis), and the Podarcis hispanicus complex (P. hispanicus sensu lato, $P$. liolepis, $P$. vaucheri and several undescribed candidate species). Furthermore, in the following species complexes, the precise distribution ranges of each species need to be determined (preferably using genetic methods; Joger et al., 2007) and the available records (and new future records) need to be refined to distinguish between the different species: Triturus marmoratus/pygmaeus, Triturus carnifex/cristatus/dobrogicus/karelinii/ macedonicus, Blanus cinereus/mariae, Psammodromus hispanicus complex ( $P$. edwardsianus, P. hispanicus, and P. occidentalis), Vipera ursinii/renardi, and Zamenis longissimus/lineatus. This list of taxa in need of taxonomic and distributional revision is clearly not exhaustive and was driven by the particular problems that we have identified while assembling the distributional data sets. It is clear that taxonomic revision is also needed in other species of European amphibians and reptiles, especially those in south-eastern Europe. Indeed, even for the most studied complexes, such 
as the crested newts (Wielstra and Arntzen, 2011), reliably attributing all grid cells to either of the newly recognized species within the limits of distribution of the entire complex turned out to be impossible. The issues identified here are particularly pressing, because they often concern widespread species where clarification of the exact distribution boundaries requires intensive sampling.

Subtracting the number of species (amphibians and reptiles merged) for each grid cell in the 1997 European Atlas from the respective value in our compilation yields a pattern reflecting the overall increased coverage and mapping intensity, especially in Western and Central Europe (fig. 6). However, in the new compilation a lower overall number of species per grid cell is present in some countries. This counter-intuitive pattern is partly explained by the fact that for some areas the 1997 European Atlas was based on expert opinion about the occurrence of a species in a grid cell (Gasc et al., 1997), and underlying records were not available any more for the new national atlases. Contemporary regional and national atlases, on the contrary, typically only take fully documented records into account. Moreover, we mainly compiled published data. Therefore, our compilation lacks all chorological information in personal databases or journals not available to us. For those countries where new national mapping data exist we excluded the SEH/GBIF database records from our compilation, therefore for countries such as Greece and Ukraine the current compilation contains fewer grid cell records which however are better documented than those in the 1997 European Atlas. In general, south-eastern Europe concentrates a high species richness especially of reptiles, but many countries in this area lack national atlases. Future efforts should be targeted to encourage and support national mapping efforts in this region. In addition, a European initiative might be useful to set up a mapping campaign to fill in these crucial distributional gaps.

\section{Conclusions and future tasks: the distributed database network system}

Distribution maps are ephemeral products in constant need for updating. Therefore, the most important part of a chorological atlas is its database, which should be operative for a long time. For this reason, the SEH Mapping Committee decided to implement a system of distributed online databases, as this is the only solution to avoid problems of data duplication and actualisation, and to ensure that the owners of each sub-database maintain the control over its administration. The first prototype of this system is ready (see Sillero et al., 2014). In the near future, we hope the system might connect the databases of each European country.

An important future aspect will be to standardise the date of each record in each of the national databases as well as in the SEH database (see also Denoël, 2012). At present, precise dates of observation are provided for each record in some of the databases, but completely lacking in others. Furthermore, historical records often lack any precise date. A system of minimum date (at least year) for each record needs to be implemented to allow querying the databases for possible changes in species range, e.g. in the context of both climate change and land cover use, and accurate dates would even allow evaluating phenological changes. This would imply to have multiple records for each cell grids when data are available for several years for instance.

One major problem cannot be solved by the distributed database system, namely the lack of funding and personnel in many countries to set up a national database, collect mapping data, validate each record, and feed them into the system. It therefore will be important to activate also other sources from which these data could be obtained. Distribution mapping and species monitoring are research fields with a well-developed tradition of citizen science contribution. In many countries of central and northern Europe, the bulk of amphibian and reptile distribution data are collected by volun- 


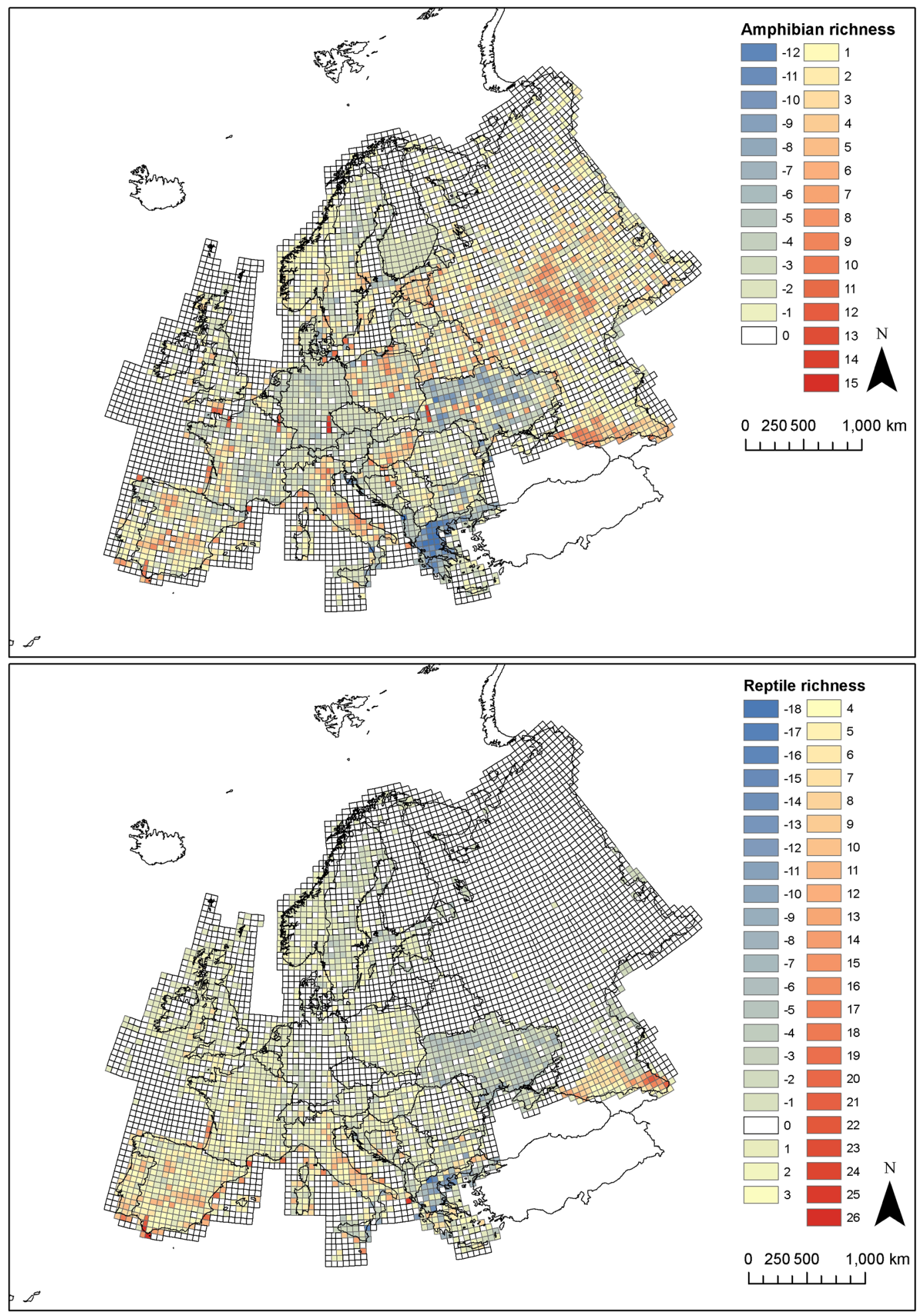

Figure 6. Differences in species richness of all non-introduced species of European amphibians and reptiles between this compilation and the 1997 European Atlas (Gasc et al., 1997). 
teers, many of which do not hold biology degrees and are not professionally working as herpetologists. We feel that activating such volunteering work especially in southern countries, and among tourists visiting these countries, should be an important resource to fill mapping gaps (Bonardi et al., 2011). Providing a common platform to enter such observations, accompanied by photographic documentation, will be a step to achieve this goal, if coupled with a functional and robust validation procedure. Such an online platform for entering data will be provided by the SEH online database system. However, major challenges remain, such as integration with other systems like iNaturalist (www.inaturalist.org), Observado.org (www.observado.org), or Telmee (www.telmee.nl), the feedback of the centrally collected data into the national databases, and especially, the review and scientific validation process before the contributed data are included in these databases (Boakes et al., 2010; Bonter and Cooper, 2012; Ficetola et al., 2013). An important point is also that each national or local database should use the same taxonomic list. Finally, there is a large variation of resolution between distribution atlases: although some use point coordinates, others provide only large areas. At the current stage, the grid size resolution of $50 \times 50 \mathrm{~km}$ reduces this problem, but in the long term, the realisation of more detailed maps would require the centralization of highly detailed data from each database.

In summary, the data presented here provide a first, tentative step towards an interactive, dynamic and distributed database of the spatial distribution of European amphibians and reptiles. The grid maps of all species made available along with this paper will facilitate conservation-related studies and actions, and will inform and guide further activities to improve and complete the database. However, it should be kept in mind that they are currently dependent on availability of digital databases, and not only on species presence or even on current knowledge on species distribution. Find- ing ways to gather all species occurrence data available in Europe is a major challenge for the future. Integrating the temporal dimension and measures of spatial uncertainty to all point records in the original databases is another necessary improvement to allow detailed modelling of the impacts of land use and climate change, and we call for concerted and varied efforts to fill the geographic and taxonomic gaps identified.

Acknowledgements. We are grateful to a large number of persons who have contributed or facilitated data, ideas information, and discussions to this project: Albert Montori, Ali Salamun, Armando Loureiro, Anamarija Zagar, Annie Zuiderwijk, Benedikt Schmidt, Burkhard Thiesmeier, Cátia Matos, Claes Andrén, Ciprian Samoila, Edmée Engel, Thierry Kinet, Dan Cogălniceanu, Daniel Jablonski, Darvin Dobrnjić, David Tarknishvilli, Elena Argaña, Elvir Tanović, Idriz Haxhiu, Jean-Christophe de Massary, Jean-Philippe Siblet, Horace Da Costa, Patrick Haffner, Benoit Lefeuvre, Jiri Moravec, Katja Poboljšaj, Marco Zuffi, Michael Veith, Miguel A. Carretero, Monika Hachtel, Nikolay Tzankov, Oldrich Kopecky, Oleksandr Zinenko, Rainer Günther, Robert Jooris, Sandra Nieto-Roman, Sergé Bogaerts, Silvia Zumbach, Wouter Beukema and Susanne Hauswaldt. Our project was based on a varied set of national and regional atlases. We are therefore very grateful to the different societies and the atlas coordinators: A. Loureiro (Portugal), Asociación Herpetológica Española (Spain), RAVON (The Netherlands), Service du Patrimoine Naturel (Muséum National d'Histoire Naturelle, France), Koordinationsstelle für Amphibien- und Reptilienschutz in der Schweiz (KARCH, Switzerland), Societas Herpetologica Italica (Italy), Natuurpunt - Hyla (Flanders), Raînne-Natagora (Wallonia and Brussels), Musée National d'Histoire Naturelle (Luxembourg), Societas Herpetologica Slovenica and Center za kartografijo favne in flore (Slovenia). We deeply thank the thousands of volunteers that contributed to the atlases and distribution databases. List of names can be found through their relevant societies and local atlases. We also thank the group of specialists of the SEH than defined the taxonomic reference list. This research project was funded by Societas Europaea Herpetologica. Authors were funded by the following institutions: the Fundação para a Ciência e Tecnologia (Portugal) grant SFRH/BPD/26666/2006 to NS, the Spanish Ministry of Environment 206/2010 grant and the BiodivERsA: EC21C to DRV, the Ministry of Education, Science and Technological Development of Republic of Serbia grant 173025 to JCI, Fonds Spéciaux de la Recherche grant C11/23 and Fonds de la Recherche Scientifique-FNRS Crédit aux Chercheurs grant 1.5.040.10.F to MD (Fonds de la Recherches Scientifique-FNRS Research associate, Belgium), the Generalitat de Catalunya FI-DGR grant, Spain to PdD, and a Georg Forster Fellowship of the Alexander von Humboldt Foundation to AR. 


\section{References}

Anthony, B., Arntzen, J.W., Baha el Din, S., Böhme, W., Cogălniceanu, D., Crnobrnja-Isailović, J., Crochet, P.-A., Corti, C., Griffiths, R., Kaneko, Y., Kuzmin, S., Lau, M.W.N., Li, P., Lymberakis, P., Marquez, R., Papenfuss, T., Pleguezuelos, J.M., Rastegar, N., Schmidt, B., Slimani, T., Sparreboom, M., Ugurtas, I., Werner, Y., Xie, F. (2008): Amphibians of the Palearctic realm. In: Threatened Amphibians of the World, p. 106-111. Stuart, S.N., Hoffmann, M., Chanson, J.S., Cox, N.A., Berridge, R.J., Ramani, P., Young, B.E., Eds, Lynx, Barcelona.

Araújo, M.B., Pearson, R.G. (2005): Equilibrium of species' distributions with climate. Ecography 5: 693-695.

Araújo, M.B., Thuiller, W., Williams, P.H., Reginster, I. (2005): Downscaling European species atlas distributions to a finer resolution: implications for conservation planning. Glob. Ecol. Biogeogr. 1: 17-30.

Araújo, M.B., Thuiller, W., Pearson, R.G. (2006): Climate warming and the decline of amphibians and reptiles in Europe. J. Biogeogr. 33: 1712-1728.

Araújo, M.B., Nogués-Bravo, D., Valdes, P.J., Rahbek, C. (2008): Quaternary climate changes explain diversity among reptiles and amphibians. Ecography 31: 8-15.

Arnold, H.R. (1995): Atlas of amphibians and reptiles in Britain. ITE research publication no. 10, London, HMSO.

Baha el Din, S., Böhme, W., Corti, C., Crnobrnja-Isailović, J., Lymberakis, P., Marquez, M., Miaud, C., Slimani, T., Ugurtas, I., Werner, Y. (2008): The status and distribution of amphibians in the Mediterranean Basin. In: Threatened Amphibians of the World, p. 113. Stuart, S.N., Hoffmann, M., Chanson, J.S., Cox, N.A., Berridge, R.J., Ramani, P., Young, B.E., Eds, Lynx, Barcelona.

Baroni-Urbani, C., Collingwood, C.A. (1976): A numerical analysis of the distribution of British Formicidae (Hymenoptera, Aculeata). Verhandl. Naturf. Ges. Basel 85: 51-91.

Baroni-Urbani, C., Collingwood, C.A. (1977): The zoogeography of ants (Hymenoptera, Formicidae) in Northern Europe. Acta Zool. Fennica 152: 2-34.

Baroni-Urbani, C., Ruffo, S., Vigna Taglianti, A. (1978): Materiali per uma biogeografia italiana fondata se alcuni generi di coleotteri cicindelidi, carabidi, e crisomelidi. Estr. Mem. Soc. Ent. Ital. 56: 35-92.

Bauwens, D., Claus, K. (1996): Verspreiding van Amfibieën en Reptielen in Vlaanderen. De Wielewaal Natuurvereniging, Turnhout, Belgium.

Bitz, A., Fischer, K., Simon, L., Thiele, R., Veith, M., Eds (1996): Die Amphibien und Reptilien in RheinlandPfalz. GNOR, Nassau, Germany.

Boakes, E.H., McGowan, P.J.K., Fuller, R.A., Ding, C.Q., Clark, N.E., O'Connor, K., Mace, G.M. (2010): Distorted views of biodiversity: spatial and temporal bias in species occurrence data. PLoS Biology 8: e1000385.

Böhm, M., Collen, B., Baillie, J.E.M., Bowles, P., Chanson, J., Cox, N., Hammerson, G., Hoffmann, M., Livingstone, S.R., Ram, M., Rhodin, A.G.J., Stuart, S.N., van Dijk, P.P., Young, B.E., Afuang, L.E., Aghasyan,
A., García, A., Aguilar, C., Ajtic, R., Akarsu, F., Alencar, L.R.V., Allison, A., Ananjeva, N., Anderson, S., Andrén, C., Ariano-Sánchez, D., Arredondo, J.C., Auliya, M., Austin, C.C., Avci, A., Baker, P.J., Barreto-Lima, A.F., Barrio-Amorós, C.L., Basu, D., Bates, M.F., Batistella, A., Bauer, A., Bennett, D., Böhme, W., Broadley, D., Brown, R., Burgess, J., Captain, A., Carreira, S., Castañeda, M.D.R., Castro, F., Catenazzi, A., CedeñoVázquez, J.R., Chapple, D.G., Cheylan, M., CisnerosHeredia, D.F., Cogalniceanu, D., Cogger, H., Corti, C., Costa, G.C., Couper, P.J., Courtney, T., CrnobrnjaIsailovic, J., Crochet, P.-A., Crother, B., Cruz, F., Daltry, J.C., Daniels, R.J.R., Das, I., de Silva, A., Diesmos, A.C., Dirksen, L., Doan, T.M., Dodd, C.K., Doody, J.S., Dorcas, M.E., Duarte de Barros Filho, J., Egan, V.T., El Mouden, E.H., Embert, D., Espinoza, R.E., Fallabrino, A., Feng, X., Feng, Z.-J., Fitzgerald, L., FloresVillela, O., França, F.G.R., Frost, D., Gadsden, H., Gamble, T., Ganesh, S.R., Garcia, M.A., García-Pérez, J.E., Gatus, J., Gaulke, M., Geniez, P., Georges, A., Gerlach, J., Goldberg, S., Gonzalez, J.-C.T., Gower, D.J., Grant, T., Greenbaum, E., Grieco, C., Guo, P., Hamilton, A.M., Hare, K., Hedges, S.B., Heideman, N., HiltonTaylor, C., Hitchmough, R., Hollingsworth, B., Hutchinson, M., Ineich, I., Iverson, J., Jaksic, F.M., Jenkins, R., Joger, U., Jose, R., Kaska, Y., Kaya, U., Keogh, J.S., Köhler, G., Kuchling, G., Kumlutaş, Y., Kwet, A., La Marca, E., Lamar, W., Lane, A., Lardner, B., Latta, C., Latta, G., Lau, M., Lavin, P., Lawson, D., LeBreton, M., Lehr, E., Limpus, D., Lipczynski, N., Lobo, A.S., López-Luna, M.A., Luiselli, L., Lukoschek, V., Lundberg, M., Lymberakis, P., Macey, R., Magnusson, W.E., Mahler, D.L., Malhotra, A., Mariaux, J., Maritz, B., Marques, O.A.V., Márquez, R., Martins, M., Masterson, G., Mateo, J.A., Mathew, R., Mathews, N., Mayer, G., McCranie, J.R., Measey, G.J., Mendoza-Quijano, F., Menegon, M., Métrailler, S., Milton, D.A., Montgomery, C., Morato, S.A.A., Mott, T., Muñoz-Alonso, A., Murphy, J., Nguyen, T.Q., Nilson, G., Nogueira, C., Núñez, H., Orlov, N., Ota, H., Ottenwalder, J., Papenfuss, T., Pasachnik, S., Passos, P., Pauwels, O.S.G., Pérez-Buitrago, N., Pérez-Mellado, V., Pianka, E.R., Pleguezuelos, J., Pollock, C., Ponce-Campos, P., Powell, R., Pupin, F., Quintero Díaz, G.E., Radder, R., Ramer, J., Rasmussen, A.R., Raxworthy, C., Reynolds, R., Richman, N., Rico, E.L., Riservato, E., Rivas, G., da Rocha, P.L.B., Rödel, M.-O., Rodríguez Schettino, L., Roosenburg, W.M., Ross, J.P., Sadek, R., Sanders, K., SantosBarrera, G., Schleich, H.H., Schmidt, B.R., Schmitz, A., Sharifi, M., Shea, G., Shi, H.-T., Shine, R., Sindaco, R., Slimani, T., Somaweera, R., Spawls, S., Stafford, P., Stuebing, R., Sweet, S., Sy, E., Temple, H.J., Tognelli, M.F., Tolley, K., Tolson, P.J., Tuniyev, B., Tuniyev, S., Üzüm, N., van Buurt, G., Van Sluys, M., Velasco, A., Vences, M., Veselý, M., Vinke, S., Vinke, T., Vogel, G., Vogrin, M., Vogt, R.C., Wearn, O.R., Werner, Y.L., Whiting, M.J., Wiewandt, T., Wilkinson, J., Wilson, B., Wren, S., Zamin, T., Zhou, K., Zug, G. (2013): The conservation status of the world's reptiles. Biol. Conserv. 157: $372-385$ 
Bonardi, A., Manenti, R., Corbetta, A., Ferri, V., Fiacchini, D., Giovine, G., Macchi, S., Romanazzi, E., Soccini, C., Bottoni, L., Padoa Schioppa, E., Ficetola, G.F. (2011): Usefulness of volunteer data to measure the large scale decline of "common" toad populations. Biol. Conserv. 144: 2328-2334.

Bonter, D.N., Cooper, C.B. (2012): Data validation in citizen science: a case study from Project FeederWatch. Front Ecol. Environ. 10: 305-309.

Bunce, R.H., Carey, P., Elena-Rossello, R., Orr, J., Watkins, J., Fuller, R. (2002): A comparison of different biogeographical classifications of Europe, Great Britain and Spain. J. Environ. Managem. 2: 121-134.

Cabela, A., Grillitsch, H., Tiedemann, F. (2001): Atlas zur Verbreitung und Ökologie der Amphibien und Reptilien in Österreich: Auswertung der herpetofaunistischen Datenbank der herpetologischen Sammlung des naturhistorischen Museums in Wien. Umweltbundesamt, Vienna, Austria.

Cheers, C. (2005): Geographica - The Complete Illustrated Atlas of the World. Random House, Australia.

Cogălniceanu, D., Szekely, P., Samoilă, C., Iosif, R., Tudor, M., Plăiaşu, R., Stănescu, F., Rozylowicz, L. (2013a): Diversity and distribution of amphibians in Romania. ZooKeys 296: 35-57.

Cogălniceanu, D., Rozylowicz, L., Székely, P., Samoilă, C., Stănescu, F., Tudor, M., Székely, D., Iosif, R. (2013b): Diversity and distribution of reptiles in Romania. ZooKeys 341: 49-76.

Corti, C., Nistri, A., Poggesi, M., Vanni, S. (1991): Biogeographical analysis of the Tuscan herpetofauna (Central Italy). Rev. Esp. Herp. 5 [1990]: 51-75.

Corti, C., Lo Cascio, P., Vanni, S., Turrisi, G.F., Vaccaro, A. (1997): Amphibians and Reptiles of the circumsicilian islands: new data and some considerations. Boll. Mus. Reg. Sci. Nat. Torino 15 (1): 179-211.

Corti, C., Masseti, M., Delfino, M., Perez-Mellado, V. (1999): Man and herpetofauna of the Mediterranean islands. Rev. Esp. Herp. 13: 83-100.

Corti, C., Capula, M., Luiselli, L., Sindaco, R., Razzetti, E., Eds (2010): Fauna d'Italia, Vol. XLV, Reptilia. Calderini, Bologna, Italy.

Cox, N., Chanson, J., Stuart, S. (2006): The Status and Distribution of Reptiles and Amphibians of the Mediterranean Basin. Gland, Switzerland and IUCN, Cambridge, UK.

Creemers, R.C.M., van Delft, J.J.C.W., Eds (2009): De Amfibieën en Reptielen van Nederland. - Nederlandse Fauna. Nationaal Natuurhistorisch Museum Naturalis, European Invertebrate Survey - Leiden, Netherlands.

Crisp, M.D., Laffan, S., Linder, H.Ü., Monro, A. (2001): Endemism in the Australian flora. J. Biogeogr. 28: 183198.

Danho, N. (2003): Endemicity tools. ESRI Support. http:// arcscripts.esri.com/details.asp?dbid=14537 (accessed: November 2012).

Denoël, M. (2012): Newt decline in Western Europe: highlights from relative distribution changes within guilds. Biodivers. Conserv. 21: 2887-2898.
Ficetola, G.F., Bonardi, A., Sindaco, R., Padoa-Schioppa, E. (2013): Estimating patterns of reptile biodiversity in remote regions. J. Biogeogr. 40: 1202-1211.

Gasc, J.-P., Cabela, A., Crnobrnja-Isailović, J., Dolmen, D., Grossenbacher, K., Haffner, P., Lescure, J., Martens, H., Martínez-Rica, J.P., Maurin, H., Oliveira, M.E., Sofianidou, T.S., Veith, M., Zuiderwijk, A. (1997): Atlas of Amphibians and Reptiles in Europe. Societas Europaea Herpetologica and Muséum national d'Histoire naturelle, Paris.

Głowaciński, Z., Rafiński, J., Eds (2003): Atlas płazów i gadów Polski. Status - Rozmieszczenie - Ochrona. Inspekcja Ochrony Środowiska, Instytut Ochrony Przyrody PAN, Warszawa-Kraków, Poland.

Günther, R., Ed. (1996): Die Amphibien und Reptilien Deutschlands. Gustav Fischer Verlag, Jena.

Hofer, U., Monney, J.-C., Dušej, G. (2001): Die Reptilien der Schweiz: Verbreitung, Lebensräume, Schutz / Les Reptiles de Suisse: Répartition, Habitats, Protection / I Rettili della Svizzera: Distribuzione, Habitat, Protezione. Birkhäuser, Basel.

Hopkins, W.A. (2007): Amphibians as models for studying environmental change. Ilar. J. 48: 270-277.

IUCN (International World Conservation Union) (2001): IUCN red list categories. Version 3.1. Species Survival Commission, IUCN, Gland, Switzerland, and Cambridge, United Kingdom.

IUCN (International World Conservation Union) (2012): The IUCN Red List of Threatened Species. Version 2012.2. http://www.iucnredlist.org. Downloaded on 17 October 2012.

Jacob, J.-P., Percsy, C., de Wavrin, H., Graitson, E., Kinet, T., Denoël, M., Paquay, M., Percsy, N., Remacle, A. (2007): Amphibiens et Reptiles de Wallonie. Série Faune - Flore - Habitats $n^{o}$ 2. Aves - Raînne et Direction Générale des Ressources naturelles et de l'Environnement, Ministère de la Région wallonne, Namur, Belgium.

Jalas, J., Suonuinen, J. (1972): Atlas Florae Europaea. Distribution of Vascular Plants in Europe, Vol. 1: Pteridophyta. (T. C. for Mapping the Flora of Europe and Societas Biologica Fennica Vanamo, Ed.). Helsinki, Finland.

Jetz, W., McPherson, J.M., Guralnick, R.P. (2011): Integrating biodiversity distribution knowledge: toward a global map of life. Trends. Ecol. Evol. 27: 151-159.

Joger, U., Fritz, U., Guicking, D., Kalyabina-Hauf, S., Nagy, Z.T., Wink, M. (2007): Phylogeography of western Palaearctic reptiles - Spatial and temporal speciation patterns. Zoolr. Anz. 246: 293-313.

Kuzmin, S.L. (2013): The Amphibians of the Former Soviet Union. Pensoft Publisher, Sofia and Moscow.

Kypnjehko, B.E., Bepbec, H.T. (1999): Amphibians and Reptiles of Ukraine. Genesa, Kiev.

Laffan, S.W., Crisp, M.D. (2003): Assessing endemism at multiple spatial scales, with an example from the Australian vascular flora. J. Biogeogr. 30: 511-520.

Laffan, S.W., Ramp, D., Roger, E. (2012): Using endemism to assess representation of protected areas - the family Myrtaceae in the Greater Blue Mountains World Heritage Area. J. Biogeogr. 40: 570-578. 
Lanza, B., Andreone, F., Bologna, M.A., Corti, C., Razzetti, E., Eds (2007): Fauna d'Italia, Vol. XLII, Amphibia. Calderini, Bologna, Italy.

Laufer, H., Klemens, F., Sowig, P., Eds (2007): Die Amphibien und Reptilien Baden-Württembergs. Ulmer Verlag, Stuttgart.

Lescure, J., de Massary, J.C., Eds (2013): Atlas des Amphibiens et Reptiles de France. Muséum National d'Histoire Naturelle. Biotope Eds, Paris.

Longley, P.A., Goodchild, M.F., Maguire, D.J., Rhind, D.W. (2010): Geographical Information Systems and Science, 3rd Edition. John Wiley, New York.

Loureiro, A., Ferrand, N., Carretero, M.A., Paulo, O. (2010): Atlas dos Anfíbios e Répteis de Portugal. Sfera do Caos, Lisboa.

Loureiro, A., Sillero, N. (2010): Metodologia. In: Atlas dos anfíbios e répteis de Portugal, p. 66-74. Loureiro, A., Ferrand, N., Carretero, M.A., Paulo, O., Eds, Esfera do Caos, Lisboa.

Mertens, R., Wermuth, H. (1960): Die Amphibien und Reptilien Europas. (Dritte Liste, nach dem Stand vom 1. Januar 1960). Frankfurt am Main, Verlag Waldemar Kramer.

Meyer, A., Zumbach, S., Schmidt, B., Monney, J.-C. (2009): Les Amphibiens et les Reptiles de Suisse Bern, Switzerland. Haupt Verlag.

Oksanen, J., Blanchet, F.G., Kindt, R., Legendre, P., Minchin, P.R., O’Hara, R.B., Simpson, G.L., Solymos, P., Stevens, M.H.H., Wagner, H. (2012): vegan: Community Ecology Package. R package version 2.0-5. http:// CRAN.R-project.org/package $=$ vegan

Olivero, J., Real, R., Márquez, A.L. (2011): Fuzzy chorotypes as a conceptual tool to improve insight into biogeographic patterns. Systc. Biol. 60: 645-660.

Pleguezuelos, J.M., Ed. (1997): Distribución y Biogeografía de los Anfibios y Reptiles en España y Portugal. Asociación Herpetológica Española - Universidad de Granada, Spain.

Pleguezuelos, J.M., Márquez, R., Lizana, M., Eds (2002): Atlas y Libro Rojo de los Anfibios y Reptiles de España. Dirección General de la Conservación de la naturaleza-Asociación Herpetológica Española ( $2^{\mathrm{a}}$ impresión). Madrid, Spain.

Proess, R., Ed. (2003): Verbreitungsatlas der Amphibien des Grossherzogtums Luxemburg. Ferantia 37, Travaux Scientifiques du Musée national d'Histoire naturelle, Luxembourg.

Proess, R., Ed. (2007): Verbreitungsatlas der Reptilien des Großherzogtums Luxemburg. Ferantia 37, Travaux Scientifiques du Musée national d'histoire naturelle, Luxembourg.

Puky, M., Schad, P., Szövenyi, G. (2006): Herpetological atlas of Hungary/Magyarorszag herpetologiai atlasza. IUCN SSC Hungary.

R Development Core Team (2012): R: a Language and Environment for Statistical Computing. R Foundation for Statistical Computing, Vienna, Austria. ISBN 3900051-07-0, URL http://www.R-project.org/.

Rueda, M., Rodríguez, M.A., Hawkins, B.A. (2010): Towards a biogeographic regionalization of the European biota. J. Biogeogr. 11: 2067-2076.
Sillero, N. (2011): What does ecological modelling model? A proposed classification of ecological niche models based on their underlying methods. Ecol. Model. 222: 1343-1346.

Sillero, N., Celaya, L., Martín-Alfageme, S. (2005): Using GIS to make an atlas: A proposal to collect, store, map and analyse chorological data for herpetofauna. Rev. Esp. Herpetol. 19: 87-101.

Sillero, N., Brito, J.C., Toxopeus, B., Skidmore, A.K. (2009): Biogeographical patterns derived from remote sensing variables: the amphibians and reptiles of the Iberian Peninsula. Amphibia-Reptilia 30: 185-206.

Sillero, N., Amaro, M., Sousa, F., Sousa, P., GonçalvesSeco, L. (2014): Distributed database system of the new atlas of amphibians and reptiles in Europe: the NA2RE project. Amphibia-Reptilia 35: 33-39.

Sindaco, R., Doria, G., Razzetti, E., Bernini, F., Eds (2006): Atlante degli Anfibi e dei Rettili d'Italia/Atlas of Italian Amphibians and Reptiles. Societas Herpetologica Italica. Edizioni Polistampa, Firenze, Italy.

Sinervo, B., Méndez-de-la-Cruz, F., Miles, D.B., Heulin, B., Bastiaans, E., Villagrán-Santa Cruz, M., Lara-Resendiz, R., Martínez-Méndez, N., Calderón-Espinosa, M.L., Meza-Lázaro, R.N., Gadsden, H., Avila, L.J., Morando, M., De la Riva, I.J., Victoriano Sepulveda, P., Rocha, C.F., Ibargüengoytía, N., Aguilar Puntriano, C., Massot, M., Lepetz, V., Oksanen, T.A., Chapple, D.G., Bauer, A.M., Branch, W.R., Clobert, J., Sites, J.W. Jr. (2010): Erosion of lizard diversity by climate change and altered thermal niches. Science 328: 894-899.

Speybroeck, J., Beukema, W., Crochet, P.A. (2010): A tentative species list of the European herpetofauna (Amphibia and Reptilia): an update. Zootaxa 2492: 1-27.

Stuart, S.N., Chanson, J.S., Cox, N.A., Young, B.E., Rodrigues, A.S.L., Fischman, D.L., Waller, R.W. (2004): Status and trends of amphibian declines and extinctions worldwide. Science 306: 1783-1786.

Valakos, E., Pafilis, P., Sotiropoulos, K., Lymberakis, P., Maragou, P., Foufopoulos, J. (2008): The Amphibians and Reptiles of Greece. Edition Chimaira, Frankfurt am Main.

Vences, M., Guayasamin, J.M., Miralles, A., de la Riva, I. (2013): To name or not to name: Criteria to promote economy of change in Linnaean classification schemes. Zootaxa 3636: 201-244.

Vigna Taglianti, A., Audisio, P., Biondi, M., Bologna, M.A., Carpaneto, G.M., De Biase, A., Fattorini, S., Piattella, E., Sindaco, R., Venchi, A., Zapparoli, M. (1999): A proposal for a chorotype classification of the Near East fauna, in the framework of the Western Palearctic region. Biogeographia 20: 31-59.

Wake, D.B., Vredenburg, V.T. (2008): Are we in the midst of the sixth mass extinction? A view from the world of amphibians. Proc. Natl. Acad. Sci. USA 105: 1146611473.

Weiserbs, A., Jacob, J.P. (2005): Amphibiens et Reptiles de la Région de Bruxelles-Capitale. Aves \& Institut Bruxellois pour la Gestion de l'Environnement, Bruxelles, Belgium. 
Wielstra, B., Arntzen, J.W. (2011): Unraveling the rapid radiation of crested newts (Triturus cristatus superspecies) using complete mitogenomic sequences. BMC Evol. Biol. 11: 162 .
Submitted: September 2, 2013. Final revision received: December 23, 2013. Accepted: January 14, 2014.

Associated Editors: Sylvain Ursenbacher and Sebastian Steinfartz. 